\title{
On the Name of God and the Opening of New Linguistic Horizons
}

Considerations Starting from the Bible, Hölderlin, and Rilke

\author{
Jakob Helmut Deibl
}

Dear Kurt!

Summer 2013

Thank you very much for the invitation to write a reply to your inaugural lecture "Christianity as a New Humanism" I was very happy about it and would like to accept your invitation in form of a letter.

\section{Preliminary Note}

The basic scheme of the lecture is a distinctive three-part structure based on three reference texts: the biblical primeval history (Gen 1-11), Hegel's Phenomenology of Spirit and Musil's Man without Qualities.

At the beginning there is an interpretation of the two inextricably entangled biblical stories of creation (Gen 1-3). Both texts refer to an element of pure excess that cannot be located, to an open space whose indisposability [Unverfügbarkeit] represents a barrier to a totalizing, appropriating view and thus the opening of a spiritual element, namely the seventh day and the tree of knowledge. However, the accounts describe the failure in dealing with this elusive element, which disappears in the face of an attitude shaped by a boundless desire to possess. The dislocation from paradise, which constitutes God's answer to this, represents the restoration of distance and the "decentration" of the ego's desire for a total view. The ambivalent gift of mortality that accompanies this can be equated to man's protection from the phantasm of having himself, as well as the Other, entirely at his disposal.

At this point the lecture proceeds to its second reference text, Hegel's Phenomenology of Spirit, and presents a sequence of different attempts by the ego to achieve the aforementioned total view by projecting itself into the world it encounters, which involves particular conceptions of history. Each of

1 Inaugural lecture at the University of Vienna on June 21, 2012, slightly modified in this volume under the title "Christianity and a New Humanism: Historical-Theoretical and Theological Reflections on the Bible, Hegel, and Musil". 
the ego's attempts to find itself completely in the world, however, must fail and ends, so to speak, with the figure of a farewell, just as at the end of the paradise story. What takes place in connection with this is the dissolution of the corresponding conceptions of history. The driving force of these conceptions is the desire to overcome the contingency of history and, consequently, represents a bounded, non-free way of dealing with it. This (ambivalent) path of desperation (Hegel) ultimately leads to a new perspective on religion. Instead of fixed regulations, it allows the category of transition (Übergang) to increasingly emerge. Instead of the constant attempts of the ego to find itself in certain projections and to hide its own finitude, a new form of human tangibility is found, a second body of pure tangibility and exposure. The category of transition does not imply a transition from one fixed determination to another, but rather indicates an event (Ereignis), in which relationships and their meaning are constituted in the first place. This again opens up a spiritual view, which had been prevented previously by the appropriating desire in the paradise story. Which representation of history could correspond to this newly arisen perspective?

The third section of the lecture is dedicated to the Book of Revelation and Musil's Man without Qualities and seeks to interpret the time after the end of certain conceptions of history as the "epilogue to history"2. The epilogue does not represent an arbitrary, self-contained conception of history but is merely an afterword that has ceased to take possession of reopened time after the rupture of all systems of history. Moreover, the epilogue could also be interpreted as the temporal form par excellence of Christianity, for from its viewpoint the decisive event of the Incarnation has already taken place, and the subsequent story can be read and fashioned as its epilogue. The time of the epilogue could also be thought of as the temporal form corresponding to a new humanism, especially since it challenges us with a perception in which the human is no longer protected and distorted by the masks of hitherto valid systems of meaning.

This hints at the concern of the inaugural lecture, which is expressed programmatically in its first sentence: to "lay bare a certain perspective on the human condition, which must precede any approach to the question of humanism"3. The most important logical category that is developed is that of transition; the most important temporal and linguistic category is that of the epilogue, and the motif that guides the question regarding a new humanism is the tangibility of man in contingent encounters.

2 K. Appel, Christianity and a New Humanism, Preliminary Remarks, 1.

3 K. Appel, Christianity and a New Humanism, Preliminary Remarks, 1. 
To the path you have taken, which is summarized here in brief, I would like to add a parallel line that leads from the story of Cain and Abel via Hölderlin's elegy Heimkunft (Homecoming) on to Rilke's Stundenbuch (Book of Hours). One could also speak of three transitions: The first leads from the paradise story to the tale of Cain and Abel and continues the contemplation of the biblical text at the precise point where you leave it, on the basis of the categories that you developed. It thus results from continued reading. The second leads from Hegel's philosophy to Hölderlin's poetry and refers to a friendship in thought, while simultaneously undergoing a transformation of linguistic expression. The third leads from Musil to Rilke and alludes to a contemporaneity that can never be intentionally constructed, but rather arises from a shared horizon, a generality that always already precedes us. It seems to me that Musil and Rilke share the concern of expressing this enigma through language.

As far as the form of my text is concerned, one could speak of a further transition leading from the lecture to a letter. From a Christian point of view, the letter form has permanently oriented all subsequent writing, since it not only represents the most frequently applied literary genre of the New Testament in quantitative terms, but also defines its temporal boundaries: It is the oldest form of Christian writing (First Letter to the Thessalonians) and also marks the end of the development of the texts considered canonical (Second Letter of Peter). ${ }^{4}$

I would like to add to your concern, which is of great importance for me, the question of whether a certain opening towards a new language should not go hand in hand with that perspective on the human which must precede any approach to humanism. This is what I am trying to show by accentuating the fragile line of poetry that runs alongside and presupposes the philosophical one you have elucidated. Whilst your remarks are pervaded by the effort to

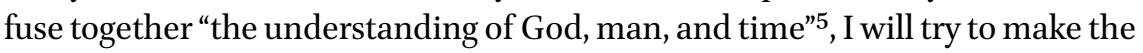
question of language audible in the texture that you explicate. At the beginning of the section of your lecture focusing on Hegel, we read that 'Self' and

4 The epistolary form of this text is not intended to imply an explicit discussion of Heidegger's famous Letter on Humanism. References could, however, be established on the basis of the opening to a new language, as well as Heidegger's reference to Hölderlin: "Hölderlin, on the other hand, does not belong to "humanism" - one must keep in mind that in this text Heidegger equates humanism with a dispositive understanding of man, in contrast to which he would like to suggest an original thinking of man - "precisely because he thought the destiny of man's essence in a more original way than 'humanism' could." (M. Heidegger, Basic Writings, New York 2008, 225.)

5 K. Appel, Christianity and a New Humanism, Preliminary Remarks, 1. 
'world' (and 'language') are correlative entities". ${ }^{6}$ Whilst your considerations focus above all on the conceptions of self and world which change together, I would like to dedicate my supplementary remarks on your lecture to the parenthetically referenced language: How does language arise from the forming of self and world?

\section{From the Gift of Mortality to the Name of God}

The inaugural lecture showed that the First Creation Story (Priestly source) and the story of the Garden of Eden and the Fall (Gen 1-3) can be read as one pericope. On this basis, the dislocation from the garden, as well as the gift of mortality, can be seen as "restitution measures, simulacra of the original protection"7 that the deprivation of the tree of knowledge (as well as of the seventh day) represents. The story of Cain and Abel (Gen 4) - which begins precisely where the considerations of the inaugural lecture leave the biblical text - builds on this and presents two opposing tendencies in dealing with the protection granted by God: on the one hand, the continuation of the desire for a total view, which is perennial and appears in ever new disguises, and, on the other hand, the dawning perception of an elusive element in encounters, ruptures, transitions and shifts. As will be shown, two different forms of understanding history are connected to these tendencies. From the inaugural lecture I would like to draw attention to the change of perspective in the dynamics of these stories.

The first motif to pay attention to in the story of Cain and Abel is the presentation of the two brothers. One first looks at Cain: "He is the main character, the first-born son, the future head of the family, the new patriarch," ${ }^{8}$ and is presented by Eve as a man: "I have gotten a man from YHWH" (Gen 4:1). Abel, on the other hand, is not specifically brought into focus but receives his identity through Cain, as his brother: "And she again bare his brother Abel"

6 K. Appel, Christianity and a New Humanism, A. The world as Mirror of the Self and its Shattering - Consciousness, Self-Consciousness, Reason and Spirit in Hegel's Phenomenology of Spirit, 12.

7 K. Appel, Christianity and a New Humanism, B. The Gown of Grace and the Nakedness of Existence, 9.

8 K. Butting, Abel steh auf! Die Geschichte von Kain und Abel - und Schet (Gen 4,1-26), in: BiKi $5^{8}$ (2003), 16. The following considerations take their starting point from this article. See also G. Fischer, Die Anfänge der Bibel. Studien zu Genesis und Exodus (Stuttgarter Biblische Aufsatzbände 49), Stuttgart 2011, 42 et seq. I would like to thank Rita Perintfalvi for numerous references. 
(Gen 4:2). While God was the inaccessible reference point at Cain's birth, Cain moves over to this position at Abel's birth. A certain concept of strength and genealogical continuity, as represented by the first-born, takes over God's position, which initially represents the open center of the event of the passing on of life. The names are also telling: "Cain" can be connected with to acquire and possession", while "Abel" means breeze:

Everything suggests that the name is to denote the breeze-like nature of the fleeting life of the slain and generally 'the evanescence or nothingness of man also as a possibility of being human together' (Westermann .... $)^{10}$.

With his name Abel thus assumes the gift of mortality. While Cain is subsequently portrayed as acting and speaking, Abel appears merely as an imitator; thus, like Cain, he offers his sacrifice (Gen 4:3). Cain is God's interlocutor, whereas Abel remains silent.

The view presented here replaces the open space associated with God with a perspective that is captured by the history of the strong and whose center of reference regarding relationships, orientations and desires resides in this history. This initial situation reiterates the perspective that arises in the story of the Garden of Eden, when its open space becomes occupied by the displaced tree of knowledge, which at first could not be localized but now has "moved [to] center stage in place of the tree of life, and is thus placed at the heart of human desire"11. As a counter-movement to this, God invites Cain to a change of perspective which takes the brother in need into consideration and shows responsibility towards him: God looks at the sacrificed Abel and helps Cain by indicating the direction in which he too should look. Cain, however, lowers his gaze to the ground and in doing so refuses to look in the same direction as God. God addresses this misguided gaze by saying: "Why are you angry? Why is your countenance fallen? If you do well, shall you not be accepted?" (Gen 4:6) Cain does not accept this invitation - the only scene in which he turns to Abel ends with the latter's murder. Abel as a mortal being, who carries mortality in his very name, is not protected by Cain; rather, Cain wants to pin him down with his mortality. This is the first death that is mentioned in the Bible.

Why did Cain, a powerful man who lacked nothing, murder Abel? Cain does not adopt God's perspective, but instead strives to secure for himself the only

9 Cf. K. Butting, Abel steh auf!, 16.

10 K. Seybold, הֶבֶ, Art., in: Theologisches Wörterbuch zum Alten Testament II, Stuttgart/ Berlin/Köln/Mainz 1977, 334-343, here: 337 .

11 K. Appel, Christianity and a New Humanism, B. The Gown of Grace and the Nakedness of Existence, 7 . 
thing that seems to be unavailable, namely God's gaze on the sacrifice offered to him. By having to see how God looks at the sacrificed Abel, it becomes clear to him that God's gaze represents something that eludes him. In it he encounters once again the open space that had appeared in connection with the seventh day and in the non-locatableness of the tree of knowledge. Cain recognizes that even the power of primogeniture, which is based on genealogy, i.e., on the "attempt to gain immortality through descendants,"12 cannot get hold of this moment and take possession of it. ${ }^{13}$ Hence, a gap appears in his own name, too. The elimination of Abel was intended to erase every reminder that the very genealogy in which Cain stands and the very right of primogeniture which he possesses are limited by God's inaccessible gaze, as well as by mortality itself. By murdering Abel, he wanted to make himself master of life and death, which the displacement away from the tree of life had intended to prevent, on the one hand, and on the other hand, to draw to himself God's gaze, in which God himself had invited him to participate (Gen 4:4-7). However, he cannot withstand its immediacy: "from Thy face shall I be hid" (Gen 4:14). Yet, whoever looks in the same direction as God (i.e., turns his gaze to those in need of attention) escapes his consuming gaze and maintains the boundary against deadly immediacy with God (Ex 33:18-23). ${ }^{14}$

Cain receives a protective mark (Gen 4:15) and does not fall prey to revenge. His genealogy subsequently develops very successfully. Beginning with Cain, seven generations are described, which allow the entire cultural world of mankind to come into being in triumph, as it were: the foundation of cities as centers of cultural development, livestock farming as domestication of nature, the invention of handcraft for the production of tools and weapons and the founding of the arts. From the perspective of the Bible, however, this cultural development is no guarantee for increasing humanization, but instead carries with it the shadow of rampant violence, as the figure of Lamech shows (Gen 4:23 et seq.). Cain's genealogy culminates in Lamech's heroic song glorifying violence:

While (as opposed to the behavior of the first humans) the defiance of Cain's response to God is striking (4:9), Lamech's will to self-assert with respect to men, but also with respect to God, has become boundless. ${ }^{15}$

12 K. Appel, Christianity and a New Humanism, B. The Gown of Grace and the Nakedness of Existence, 10.

13 Cf. the meaning for the name Cain!

14 This call for a certain perspective is probably also the reason behind Jesus' urgent admonition to Peter: "Get thee behind Me, Satan" (Mk 8:33).

15 E. Drewermann, Strukturen des Bösen. Teil 1. Die jahwistische Urgeschichte in exegetischer Sicht, Paderborn/München/Wien/Zürich 1988, 156; cf. 155-161, 164-17o. 
The figure of Lamech thus follows the approach of making one's own desire an all-encompassing point of reference, beginning with the tree of knowledge becoming more and more clearly localizable. Starting with Cain, this point of reference is inevitably passed on to the following generations, in genealogical necessity.

At this point, however, a change of perspective takes place, which both allows us to see the peculiarity of the biblical story and also prevents the Cain/ Lamech line from becoming our universal understanding of history. In order to work out the characteristics of the story of Cain and Abel, let us now ask about its parallels to and differences from the founding history of Rome, namely Romulus' fratricide of Remus. The basic structure seems similar: Urban cultural development is preceded by fratricide; the victory of the stronger one of the two is followed by a story of success. However, the theme of taking sides with the weaker one, which is central to the biblical narrative from the beginning, does not appear. The Roman narrative remains spellbound by the success story, and every mention of the city's name from now on refers to its victorious founder. All it knows of Remus is that he is buried on the Aventine. The biblical narrative is different; it is interested in Abel's being mentioned. He who remained mute until his murder, whose muteness was to be sealed by his murder, is given language. His blood cries out from the soil to God, who hears his cry (Gen 4:10): "Cain wanted to be done with Abel. But he is not to be done with; the life that has been spilled cries out."16 The brief description of Cain's success story, for which the Bible spares merely eight verses (Gen 4:17-24), is followed by a look back at Abel. Eve "bore a son and called his name Seth: For God, said she, hath appointed me another seed instead of Abel, whom Cain slew." (Gen 4:25) Seth, whose name means substitute, takes the place of Abel and has the duty of carrying on the memory of his brother's discontinued genealogy. Whereas Cain refused to care for Abel, and Lamech's relationship with the Other is one of threats and boastfulness, Seth himself becomes the embodiment of someone who keeps an eye out for his brother. He is a complete substitute; his identity does not consist in the attempt to put himself at the center and to claim a totalizing gaze for himself, but rather it consists in reference to the Other - namely to the one who has neither a history nor a voice of his own.

When the Gospel of Luke enumerates Joseph's ancestors - and thus, before one can get to know him from his ministry, introduces Jesus starting from the history of Israel's covenant -, not only the famous biblical figures of David, Jacob, Joseph, Isaac, Abraham, Noah, Methuselah and Enoch are mentioned, but among many others also Seth and Adam (Lk 3:23-38). This person-oriented 
depiction of salvation history does not refer to the victorious history of Cain but builds on Seth, the substitute for Abel. Biblical salvation history breaks away from the context of natural genealogy and continues a fragile story, which does not derive its logic from genealogical necessity but is an expression of covenant. It is not regulated by the natural, compulsive unambiguity following the scheme that $A$ generates $B, B$ generates $C$..., but instead it proceeds via numerous breaks and requires a narrative in which it finds coherence. In this way, it no longer represents the strong success story that continues by itself, but rather challenges us to a change of perspective that may occasionally occur. This change of perspective corresponds to the perspective with which God also tasked Cain.

From a Christian point of view, Jesus as the Messiah is the hermeneutical key that opens up a view of the Bible in its entirety. He is rooted in the fragile history of the covenant, which proceeds via Abel/Seth. Thus, it ensues that the entire Bible must be read from the perspective of this "tradition" of Abel/ Seth. However, it is not a strong counter-history to Cain's victorious history, but rather an invitation to a shift in perspective. It unfolds as Abel's surprising posthistory, which begins where his story should have ended. It is the epilogue of the mute Abel who could never raise his voice. It is an echo of the cry of Abel's blood that reaches heaven. We come thus to the moment the die is cast for how to understand history from a biblical perspective: Is it a victorious story (with its various forms of substitution, all of which understand themselves as selflegitimizing concepts), or does the Bible represent an epilogical narrative that becomes a narrative of the rejection of arbitrary, self-contained conceptions and an invitation to a reversal of perspective? At the transition from Abel to Seth, where all attempts at appropriating history are shattered, biblical history reveals itself as an epilogical narrative. In a fragile way, the Bible, in adopting this approach, repeatedly tells of such transitions which epilogically continue history where it should have ended, and ultimately becomes an invitation to continue it in various ways in later times. Christianity can thus be understood as faithfulness to this epilogical narrative and the resulting shift in perspective.

But the history of Abel/Seth has another point. Whereas Cain's victorious story leads to Lamech's heroic song glorifying violence (Gen 4:23-24), the story of Abel/Seth leads towards the naming of the name of God: "And to Seth, to him also there was born a son; and he called his name Enos: then began men to call upon the name of YHWH." (Gen 4:26) Not only is the name of YHWH thus opposed to any justification of violence, the gift of the name of God also renders audible again that open space which had shown itself in the seventh day, the tree of knowledge and the indisposability of the acceptance of the sacrifice. 
In other words, in the "indisposable time of celebration"17 of the seventh day, time refers to an open space; in the "non-occupyability of the garden of paradise"18, space refers to such a place, and in the name of God, ultimately, so does language. This openness is characterized by an exposure and vulnerability that makes the name of God disappear when it is used as a means of arbitrary control. Its meaning can never be directly expressed, which is why it marks a rift that runs through language and inserts an emptiness into it, a silence that prevents language from becoming self-contained. The invocation of the name YHWH, contrary to the series of cultural achievements on Cain's side, is the only development connected with the line Abel/Seth. The name of God thus stands for the openness that can appear at the points of rupture where genealogies and thus necessities and systematizations of any kind - remember that the genealogy is the archetypical principle of representation of necessity and systematization $^{19}$ - break off. The Bible as a whole is not only the epilogue of Abel's history, but is also carried forth in all the stories of people who guard the vulnerable openness associated with the name of God.

The naming of the name of God also goes hand in hand with a new name for man: "Enosh" means human and evokes meanings such as "to be weak" and "mortal". 20 The descendant of Seth, whose name is a reference to the Other, becomes the bearer of a new conception of humanity, which - unlike the Cain/Lamech line - does not express itself through genealogically imparted strength nor the attempt to disguise one's own mortality through heroism or cultural achievements. The naming of the name of God is connected with the gift of mortality and raises the question of what it means to be human, of what the human could be. In contrast to Cain and Lamech, who turn their gaze away from their brother and who inoculate themselves completely against the Other, Enosh and all those who continue his story will have to learn a new form of tangibility - which might be what resonates in Enoch's name in the sense of "being weak".

17 K. Appel, Christianity and a New Humanism, B. The Gown of Grace and the Nakedness of Existence, 10.

18 K. Appel, Christianity and a New Humanism, B. The Gown of Grace and the Nakedness of Existence, 10.

19 Cf. K. Heinrich, Parmenides und Jona. Vier Studien über das Verhältnis von Philosophie und Mythologie, Frankfurt a. M. 1966; idem, Gesellschaftlich vermitteltes Naturverhältnis. Begriff der Aufklärung in den Religionen und der Religionswissenschaft (Dahlemer Vorlesungen 8), Frankfurt a. M./Basel 2007.

20 Cf. F. Maass, אנ: Art., in: Theologisches Wörterbuch zum Alten Testament I, Stuttgart/ Berlin/Köln/Mainz 1973, 374 et seq. 
Unlike Adam, Enosh as a term for man "occurs almost solely in poetic texts"21 and is thus situated at the transition between poetry and prayer, where the latter is understood as the place of invocation of the name of God. Both of these forms of language are sustained by a dimension of inaccessibility and keep language open in the face of the danger of it exhausting itself through the closedness of functionality. Can poetry and prayer thus also be forms of language that express, in a condensed fashion, man's tangibility?

Reflection on the theology of the name of God in the Bible could take its starting point here. However, this will not be the subject of the following considerations. Rather, I will now turn to two important poets, first Hölderlin and then Rilke, who, in modern times, aligned themselves with the fragile tradition of invoking the name of God and express the danger of its falling silent in poetry itself.

\section{From the Category of Transition (Hegel) to the Opening of Language (Hölderlin)}

In Hölderlin's poetry, the invocation of the name of God appears in a variety of ways, and the question arises again and again as to whether language is still capable of this invocation. This is most clearly expressed in the poem Heimkunft (Homecoming) in the turn of phrase "holy names are lacking" (v. 101 $)^{22}$. This expresses a fundamental crisis, which envisages the end of the possibility of naming the name of God - and thus the entire line of Seth/ Enosh. According to Hölderlin, this crisis, in which language is no longer able to relate the sphere of God to that of man, has dramatic consequences both for man, who is threatened with becoming an uninterpretable sign, and for language, which is pushed to the verge of disintegration..$^{23}$ We could therefore speak of a crisis affecting the interlaced elements of humanism, language and religion. The concern of the poet and singer must not avoid this problem, as Hölderlin says in Homecoming only a few verses after the mention of the lack

\footnotetext{
21 Ibid., 374.

22 In the following, quoted passages from the poem Heimkunft (Homecoming) will be indicated by verse number in brackets; other poems by Hölderlin, when they are first quoted, will be indicated by title and verse number, and subsequent references by verse number only.

23 "A sign we are, without interpretation / Without pain we are and have almost / Lost language in the foreign land. (Ein Zeichen sind wir, deutungslos / Schmerzlos sind wir und haben fast / Die Sprache in der Fremde verloren.)" (Mnemosyne, Entwurf, v. 1-3, in: Friedrich Hölderlin, Hymns and Fragments, trans. Richard Sieburth, Princeton 1984, 117).
} 
of holy names: "Cares like these, whether he likes it or not, a singer / Must bear in his soul, and often, ... (Sorgen, wie diese, muß, gern oder nicht, in der Seele Tragen / Ein Sänger und oft, ...)". (v. 107 et seq.)

The following considerations attempt to approach this topic by referring to texts from three different stages of Hölderlin's oeuvre. First, we will examine poems from his youth, because they show essential motifs that remain characteristic of Hölderlin's poetry. They are closely related to a religious experience, which it is important to note in order to be able to sense the dramatic dimension of the later crisis of religion, language and humanism. Following this we will reflect on Hölderlin's student days and the years that followed, which will detail his amicable contact with Hegel and show how the development of a position on the question of religion took place in a similar manner and with great motivic proximity in both of them. In Hölderlin's case, this period corresponds to the shattering of all his certainties, at the heart of which is the crisis of religion. I will then discuss how he deals with this question by referring to Homecoming.

\section{A. Poems of Hölderlin's Youth (1784-1788) - the Name of God and the Question of Man}

As the poems of his youth show, ${ }^{24}$ Hölderlin's poetry grew out of a religious experience. At the age of 14 he wrote a poem entitled $M$. G., which probably stands for "Meinem Gott [To my God]"25. This figure of a dedication expressed through the abbreviation in the title will be repeated in a similar way in the youth poems $A n$ M. B. ${ }^{26}$ and An Meinen B. ${ }^{27}$ Moreover, dedications remain a characteristic feature of Hölderlin's poetry, which are not merely an external act and ultimately insignificant for the interpretation of the poem, but rather reach into the innermost part of language.$^{28}$ Language - as poetry and prayer show in particular - is never an anonymous process, but rather requires the fragile space which unfolds when addressing another.

24 See B. Liebrucks, "Und”. Die Sprache Hölderlins in der Spannweite von Mythos und Logos. Realität und Wirklichkeit (Sprache und Bewusstsein 7), Bern/ Frankfurt a. M./Las Vegas 1979, 251-258.

25 Cf. Hölderlin. Sämtliche Gedichte, ed. by J. Schmidt (Deutscher Klassikerverlag Volume 4), Frankfurt a. M. 2005, 519.

26 As D.E. Sattler showed, this abbreviation probably stands for Hölderlin's brother: "An meinen Bruder" [To my brother]. Cf. F. Hölderlin, 1770-1788. Nürtingen/Denkendorf/ Maulbronn. Erste Gedichte, Homer, in: ders., Sämtliche Werke, Briefe und Dokumente in zeitlicher Folge, ed. by D.E. Sattler (Bremer Ausgabe Band 1), München 2004, 104.

27 The dedication refers to Hölderlin's childhood friend Bilfinger: "An meinen Bilfinger" [To my Bilfinger]. Cf. F. Hölderlin, Erste Gedichte. Homer (Bremer Ausgabe Band 1), 127.

28 Cf. R. Zuberbühler, Hölderlin: 'Heimkunft', in: Hölderlin-Jahrbuch 19/2o (1975-1977), 61. 
M. G.

Herr! was bist du, was Menschenkinder?

Jehova du, wir schwache Sünder,

Und Engel sinds, die, Herr, dir dienen,

Wo ewger Lohn, wo Seligkeiten krönen.

${ }^{5}$ Wir aber sind es, die gefallen,

Die sträflich deiner Güte Strahlen

In Grimm verwandelt, Heil verscherzet,

Durch das der Hölle Tod nicht schmerzet.

Und doch, o Herr! erlaubst du Sündern,

${ }^{10}$ Dein Heil zu sehn, wie Väter Kindern,

Erteilst du deine Himmelsgaben,

Die uns, nach Gnade dürstend, laben.

Ruft dein Kind Abba, ruft es Vater,

So bist du Helfer, du Berater,

15Wann Tod und Hölle tobend krachen,

So eilst als Vater du zu wachen.

M. G.

Lord! what are you, what children of men?

You Jehovah, us weak sinners,

And angels are those, Lord, who serve you,

Where eternal reward, where bliss crowns.

${ }^{5}$ But we are the ones who, fallen,

The rays of your goodness

Transformed wantonly into wrath, salvation forfeited,

Through which hell's death does not hurt.

And yet, O Lord! you allow sinners

${ }^{10}$ To see your salvation, as fathers do with children,

You grant your gifts from heaven,

Which give refreshment to us, who thirst for grace.

When your child calls Abba, it calls Father,

So you are a helper, you are an adviser,

${ }^{15}$ When death and hell roar raging,

So as a father you hasten to watch over him.

The first point that has to be noted in order to interpret Hölderlin's later texts is the indistinguishability of poem and prayer. The poem begins by addressing God ("Lord!" M. G., v. 1), which is repeated throughout the entire text ("You Jehovah", v. 2; "Lord", vv. 3.9; "When your child calls Abba, it calls Father", v. 13). The second significant motif lies in the close connection and 
parallel configuration of the question of God and man, which directly follows God's being addressed: "Lord! what are you, what children of men? (Herr! was bist du, was Menschenkinder?)" (v. 1). The connection goes so far that in the second part of the question, which deals with man, the repetition of the verb is not considered necessary, which in German is actually grammatically incorrect, and the article for "children of men" is also omitted. The complete sentence should read: "Lord! what are you, what are the children of men? (Herr! was bist du, was sind die Menschenkinder?)". In German, unlike in English, the second person singular of "sein [to be]" is not identical with the third person plural: $d u$ bist/sie sind - you are/they are. The answer begins in verse 2 with a renewed invocation of God ("You Jehovah"), and subsequently with a reference to man, whose position is determined by the Fall and who is set apart from the angels who serve God (v. 3 et seq.). The third stanza (v. 9-12) brings a reversal in which God is addressed as a forgiving Father and the one who brings about good. The last stanza (v. 13-16) dynamizes the still rather static relationship between God and man of the third stanza and finds its pivotal point in the call to God: "When your child calls Abba, it calls Father / So you are a helper, you are an adviser (Ruft dein Kind Abba, ruft es Vater, / So bist du Helfer, du Berater)" (v. 13 et seq.). The invocation of the name of God is able to save fallen man from death and hell (v. 15) and indicates that God watches over man (v. 16). The third decisive point of this early poem can be perceived in the fact that the invocation of the name of God itself is made the subject of the poem and that the poem/prayer thus takes on a reflexive structure. This self-reflexive form remains characteristic of Hölderlin, inasmuch as poetry itself is ever newly thematized in his poems. Yet another motif seems to be significant for Hölderlin's subsequent evolution: The word "watch (wachen)" that concludes the poem in the German version ("So as a father you hasten to watch over him (So eilst als Vater du zu wachen.)", v. 16) becomes Hölderlin's imperative par excellence, in which his thinking reaches an important point of crystallization. This watching spans the night - guiding the way through that night without chasing it away with a phantasm of all-encompassing illumination or with a total view - and is the deepest expression of God's fidelity. Later on, Hölderlin's designation of the poet as the watcher represents the aspect in which the poet has a share in the divine. ${ }^{29}$

29 “... Meanwhile, it often seems to me / To sleep better than to be so without comrades, / To wait and do something while saying, / Don't I know, and why poets in a poor time? / But they are, you say, like priests holy to the god of wine, / Who went from country to country in holy night." (Bread and wine, v. 119-124). 
Motifs very similar to those in $M$. G. can be found in another poem from his youth, in Die Meinige. The title again represents a dedication. "Die Meinige" stands for "Die Meinigen", which equals "Those close to me". The poem again begins by addressing God ("Lord of the Worlds", Die Meinige, v. 1): "It is to be regarded as a prayer in which the relatives are included." ${ }^{30}$ Several verses are dedicated to the members of Hölderlin's family. In the section on his brother Carl, Hölderlin describes in prayer the path toward prayer; it prepares the ground from which prayer can emerge. This preparatory reflection is characterized by retrospection: "I think myself back to that time" (v. 115). The lyrical speaker tells how the flow of his playing next to the Neckar is interrupted by the experience of Tremendum et Fascinans:

\author{
${ }^{125}$ Endlich sah ich auf. Im Abendschimmer \\ Stand der Strom. Ein heiliges Gefühl \\ Bebte mir durchs Herz; und plötzlich scherzt ich nimmer, \\ Plötzlich stand ich ernster auf vom Knabenspiel.
}

Bebend lispelt ich: wir wollen beten!

${ }^{130}$ Schüchtern knieten wir in dem Gebüsche hin.

Einfalt, Unschuld wars, was unsre Knabenherzen redten -

Lieber Gott! die Stunde war so schön.

Wie der leise Laut dich Abba! nannte!

Wie die Knaben sich umarmten! himmelwärts

135Ihre Hände streckten! wie es brannte -

Im Gelübde, oft zu beten - beeder Herz!

${ }^{125}$ Finally I looked up. In the evening glow

Stood the torrent. A sacred feeling

Trembled through my heart; and suddenly I no longer joked,

Suddenly I stood up from the boys' game, more serious.

Trembling I lisped: let us pray!

${ }^{130}$ Shyly we knelt down in the bushes.

It was innocence and simplicity that spoke in our boyish hearts -

Dear God! the hour was so beautiful.

How the soft sound called you Abba!

How the boys embraced each other! skyward

135Their hands stretched out! how it burned -

The vow to pray often - in both their hearts! ${ }^{31}$

The first form of language that reopens itself to the poet, following silence in the face of the experience of nature's stillness ("In the evening glow / Stood the torrent", v. 126 et seq.), is prayer. When in prayer the prayer's becoming [das

\footnotetext{
$30 \quad$ B. Liebrucks, "Und", 251.

31 Translated by Natalie Eder.
} 
Entstehen des Gebets] and emerging into linguistic form is recounted, this again represents a reflexive structure. At its center we encounter God's being named as "Abba", and the memory of this is introduced once again through his being addressed as "Dear God! the hour was so beautiful. / How the soft sound called you Abba!" (v. 132 et seq.) This "soft sound (der leise Laut)" does not merely refer to soft speech. In German the noun "Laut" (meaning "sound" in English) is homophonous with the adjective "laut", which means "loud". Thus, the "soft sound (der leise Laut)" suggests a paradox, pointing to a form of simplicity and inseperableness that has not yet split into opposites ("soft" and "loud").

Ever since his early poems Hölderlin tried to express this simplicity when he used the word "silence". Its appearance in the text always requires a certain amount of preparation; poetry, though emerging from it, can never begin with it. In a similar way, one could say that in Hölderlin's early poetry the scattered references to silence were necessary before he could - after this preparation - finally make it a theme in its own right in the poem Die Stille. While initially it was not autonomous - i.e., it appeared adjectivally in phrases such as "You silent Moon (Du stiller Mond)" (Die Nacht v. 3) or "the silent shadows (die stillen Schatten)" (Die Unsterblichkeit der Seele, v. 8), or as a genitive construction in "the silence of the grave (des Grabes Stille)" (Das menschliche Leben v. 48) - in Die Stille the attempt to present it in its simplicity appears for the first time: "Noble silence! Lovely joygiver! (Hehre Stille! holde Freudengeberin!)" (Die Stille, v. 16) Let us note at this point that from the very beginning Hölderlin struggles to find a way to express silence as the simplicity and the resonant space from which any form of language emerges in the first place. Understood in this way, silence is the opposite of falling silent, i.e., silence and falling silent are the outermost poles that span our linguistic existence.

\section{B. Hegel and Hölderlin (1788-1800) - the Disintegration of the World of Gods and Men}

In Hölderlin's early poems God is often addressed directly, namely as "Lord", "Jehovah You", "oh Lord", "Father" and "Abba" (M. G.), "O, great Judge", "Father of mercy" (Das Erinnern), "Lord of the worlds", "Good one", "Father! loving Father" (Die Meinige), "Father, Father", "God in heaven", "my God" (Klagen. An Stella), "God" (Die Stille, Schwärmerei), "Gods" (Hero), "Dear God" (Die Meinige, Der Lorbeer, Schwärmerei). The beginning of Hölderlin's poetry knows no strict separation between poetry and prayer and is rooted in the long tradition of invoking the name of God. However, it is precisely this affiliation that becomes increasingly open to question, starting from the time of his studies at the Tübinger Stift. 
In the poem M. G. a form of security in the face of the disintegrating forces, which are addressed as sin, death and hell, can still be found in the invocation of the name of God. Subsequently, in the following years, experiences of alienation and the decay of the motifs which up till then had a guiding function but which no longer lead to a sense of security, become apparent in an ever more urgent way: The fulfillment of the present moment can no longer be affirmed; the future and utopia are shattered by the ambivalence of the French Revolution; the past of the Greek world can no longer be brought to life in memory; nature and freedom fall apart. In Hölderlin's poetry, these experiences of rupture remain present from here on and cannot be pacified by the reappropriation of a secure foundation, be it religion, the fatherland, etc. This represents a parallel to the development of the Phenomenology of Spirit, which is a path of despair and "does not necessarily culminate in a "happy ending"32. Even though Hölderlin's poems continue to address God as "Father", "Father Ether", "Prince of the Feast (Fürst des Festes)", etc., the question arises as to what else these references might mean, since religion no longer represents a final guarantee. Can it still have a unifying dimension or represent a figure of connection and reconciliation in the face of those tendencies towards disintegration?

The development of the question as to the liveliness of religion can be observed in both Hölderlin and Hegel, who were in close contact in the last decade of the 18th century. ${ }^{33}$ Their correspondence, as well as the poem Eleusis (1796), written by Hegel and dedicated to Hölderlin, bear witness to this and also reveal a close friendship. ${ }^{34}$ In 1794 Hölderlin wrote to Hegel:

32 K. Appel, Christianity and a new Humanism, A. The World as Mirror of the Self and its Shattering - Consciousness, Self-Consciousness, Reason and Spirit in Hegel's Phenomenology of Spirit, 11 .

33 On Hegel cf. K. Appel, Entsprechung im Wider-Spruch. Eine Auseinandersetzung mit dem Offenbarungsbegriff der politischen Theologie des jungen Hegel (Religion - Geschichte Gesellschaft. Fundamentaltheologische Studien 31), Münster/Hamburg/London 2003. On Hölderlin: V.L. Waibel, Kant, Fichte, Schelling, in: J. Kreuzer (eds.), Hölderlin-Jahrbuch. Leben - Werk - Wirkung, Stuttgart 2002/2011, 90-106; Dies., Wechselbestimmung. Zum Verhältnis von Hölderlin, Schiller und Fichte in Jena, in:Fichte und die Romantik. Hölderlin, Schelling, Hegel und die späte Wissenschaftslehre. 20o Jahre Wissenschaftslehre - Die Philosophie Johann Gottlieb Fichtes. Tagung der Internationalen J.G. Fichte-Gesellschaft (26. September - 1. Oktober 1994) in Jena. Fichte-Studien Bd. 12, Amsterdam 1997, 43-69.

34 Hegel and Hölderlin were obviously connected by a very cordial friendship, which becomes apparent in the letters they wrote to each other in October and November 1796, when Hölderlin was able to arrange for Hegel to become house tutor for the Gogel family: "Dearest Hölderlin! / So I will once again have the joy of hearing something from you; from every line of your letter speaks your unchanging friendship to me; I cannot tell you how 
Dear brother, I am sure that you have thought of me at times since we parted from each other with the motto - Kingdom of God! I believe that with this motto we would still recognize each other after each metamorphosis. ${ }^{35}$

Hölderlin probably took a keen interest in Hegel's ideas on religion, which were later compiled in what is known today as his Early Theological Writings. Since these were unpublished and Hegel lived at a great distance from Hölderlin by this time, Hölderlin had to be informed of them through letters from Hegel, some of which have either not been preserved or have not yet been found. In a letter that Hölderlin wrote in Jena in 1795, he refers to Hegel's preoccupation with religion:

It is certainly good in certain respects that you are working on religious concepts. [...] I have long been concerned with the ideal of a people's education, and, because you are occupied with the part of it that concerns religion, I may choose your image and your friendship as the conductor of thoughts into the outer world of the senses, and write what I might have written later, in good time, in letters to you, which you are to judge and correct. ${ }^{36}$

In 1796 Hegel dedicated the poem Eleusis ${ }^{37}$ to Hölderlin. The beginning of the poem seems to evoke motifs from Hölderlin's poetry (Eleusis, v. 1-11). It is followed by a section of 15 lines (v. 11-25), which express how much Hegel looked forward to a reunion with Hölderlin and wanted to strengthen their shared convictions. Hegel then turns to the subject of religion and describes the disintegration of the world of the ancient Greek gods and men:

much joy it gave me, and even more the hope of soon seeing and embracing you myself." Cf. the letters of October 24, 1796 from Frankfurt (to Hegel), of November 1796 from Tschugg near Erlach (to Hölderlin) and of November 20, 1796 from Frankfurt (to Hegel).

35 Letter dated July 10, 1794, from Waltershausen. In German: "Lieber Bruder! / Ich bin gewiss, dass Du indessen zuweilen meiner gedachtest, seit wir mit der Loosung - Reich Gottes! Von einander schieden. An dieser Loosung würden wir uns nach jeder Metamorphose, wie ich glaube, wiedererkennen."

36 Letter of January 26, 1795, from Jena. In German: "Daß Du Dich an die Religionsbegriffe machst, ist gewis in mancher Rüksicht gut und wichtig. [...] Ich gehe schon lange mit dem Ideal einer Volkserziehung um, u. weil Du Dich gerade mit einem Teile derselben der Religion beschäftigest, so wähl ich mir vieleicht Dein Bild und Deine Freundschaft zum conductor der Gedanken in die äußere Sinnenwelt, und schreibe, was ich vieleicht später geschrieben hätte, bei guter Zeit in Briefen an Dich, die Du beurteilen und berichtigen sollst." Cf. also the letter of November 25, 1795, from Stuttgart.

37 Hegel, Frühe Schriften (Werke 1), 230-233; see also H. Anton, 'Eleusis'. Hegel an Hölderlin, in: Hölderlin Yearbook 19/2o (1975-1977), Tübingen 1977, 285-302. 
Doch deine Hallen sind verstummt, o Göttin!

Geflohen ist der Götter Kreis zurück in den Olymp

Von den geheiligten Altären,

Geflohn von der entweihten Menschheit Grab,

${ }^{55}$ Der Unschuld Genius, der her sie zauberte! -

Die Weisheit deiner Priester schweigt; kein Ton der heil'gen Weihen

Hat sich zu uns gerettet - und vergebens sucht

Des Forschers Neugier mehr als Liebe

Zur Weisheit ... ${ }^{38}$

Even your halls have ceased to echo, Goddess!

The circle of the gods has fled back to Olympus

From the consecrated altars;

Fled from the tomb of profaned humanity,

${ }^{55}$ The innocent genius who enchanted them here! -

The wisdom of your priests is silent, not one note of the sacred

Initiations preserved for us - and in vain strive

The scholars, their curiosity greater than their love

Of wisdom ... ${ }^{39}$

A fundamental fissure runs through the ancient world. Hegel does not, however, aim primarily at a historical depiction, but rather has our (modern) epoch in mind, which he understands as suffering an irrevocable separation from Greek antiquity and the loss of that way of life which, for Hegel and Hölderlin, is paradigmatic for a living relationship between the divine and the human spheres. He uses images that Hölderlin himself takes up in a similar way in later poems (Cf. Brod und Wein, v. 59-64), and also Hegel employs in the Phenomenology of Spirit when he addresses the loss of all religion at the beginning of the chapter on The Revealed Religion. ${ }^{40}$ Eleusis describes the breaking apart of the living relationship of the world of the gods and men in a doubly expressed motion of flight: The gods have fled from the altars (Eleusis, v. $5^{2}$ et seq.) and have withdrawn from a desecrated humanity that now lies in the grave (v. 54). The gods' movement of flight is accompanied by the falling silent which surrounds the retreat of the gods (v. 51,56 et seq.) and must be considered the opposite of silence. Similar formulations can be found in Hölderlin. Hegel's phrase "Even your halls have ceased to echo, Goddess! (Doch deine

38 G.W.F. Hegel, Frühe Schriften, in: ders., Werke 1-2o (stw 6o1-62o), ed. by E. Moldenhauer und K.M. Michel, Frankfurt a. M. ${ }^{4} 1999$.

39 The English translation of the poem is taken from: Agamben, Giorgio: Language and Death: The Place of Negativity. Translated by Karen E. Pinkus with Michael Hardt, Minnesota 2006.

40 Cf. G.W.F. Hegel, Phänomenologie des Geistes, in: ders., Werke 1-2o, ed. by E. Moldenhauer and K.M. Michel, Frankfurt a. M. 1986, Volume 3, 547 et seq. 
Hallen sind verstummt, o Göttin!)" (v. 51) can be compared with Hölderlin's verse "Sound ... has long since fallen silent in the hall (Klanglos ... ists in der Halle längst)" (An die Deutschen, v. 53). In Eleusis it says: "The wisdom of your priests is silent (Die Weisheit deiner Priester schweigt)" (Eleusis, v. 56); no sound of the holy acts can get through to us any more. This is expressed by a falling silent like that which is voiced by Hölderlin in Archipelagus: "and for a long time they have not spoken / words of solace to the needy, the prophetic groves of Dodona, / The Delphic God is mute (und lang schon reden sie nimmer / Trost den Bedürftigen zu, die prophetischen Haine Dodonas, / Stumm ist der delphische Gott)" (Der Archipelagus, v. 226-228). At first, all that remains in Hegel's poem is the futility of a curiosity that has nothing in common with philosophy, since it seeks something other than "love / of wisdom (Liebe / Zur Weisheit)" (v. $5^{8}$ et seq.). Hölderlin summarizes this loss in Der Archipelagus, when he says: "It walks in the night, it dwells, as in the Orcus, / Without the divine our race (es wandelt in Nacht, es wohnt, wie im Orkus, / Ohne Göttliches unser Geschlecht)" (Der Archipelagus, v. 241 et seq.), and in Der Abschied he pronounces this disintegration of the human and the divine sphere in the harsh phrase "[...] Since the rooted / all-dividing hatred separates gods and men ([...] Seit der gewurzelte / Allentzweiende Hass Götter und Menschen trennt)" (Der Abschied, Erste Fassung, v. 13 et seq.). This separation is an expression of all the experiences of alienation and disintegration that Hölderlin had previously described in his poems ${ }^{41}$, and being all-encompassing divide it takes on the characteristics of an apocalyptic divorce. No area seems to be able to elude its disintegrating forces.

Hölderlin's epistolary novel Hyperion, also written at this time, shows vividly how this "flight" of the gods is an expression of the decay of all humanity:

You see artisans, but no men, thinkers, but no men, priests, but no men, masters and servants, but no men, minors and adults, but no men - is this not like a battlefield on which hacked-off hands and arms and every other member are scattered about, while the life-blood flows from them to vanish in the sand? ${ }^{42}$

Towards the end of this letter, the decomposition of society is summarized through the motif of the flight of the gods:

But where divine Nature and her artists are so insulted, ah! there life's greatest joy is gone, and any other star is better than earth. There men grow ever more sterile, ever more empty, who yet were all born beautiful; servility increases and with its

41 See J. Deibl, Vorbemerkungen zur Gottesfrage in Hölderlin's early poetry, in: IKaZ Communio 42 (2013), 520-534.

42 Friedrich Hölderlin, Hyperion and Selected Poems, ed. by Eric L. Santer, New York 1994, 128. Hyperion translated by Willard R. Trask, adapted by David Schwarz. 
insolence, intoxication grows with troubles and, with luxury, hunger and dread of starvation; the blessing of each year becomes a curse, and all gods flee. ${ }^{43}$

In Hyperion's subsequent last letter, the disintegrating forces again recede behind the power of nature:

'O you,' so I thought, 'with your gods, Nature! I have dreamed it out, the dream of human things, and I say, Only you live, and what they who know no peace have attempted and conceived melts away from your flame like beads of wax! ${ }^{44}$

With his destructive conduct, man will not be able to triumph over nature; however, this does not automatically lead to a rethinking of what it means to be human. It should be noted that Hölderlin addresses nature through the image of the tree of life when he asks to participate in its becoming green anew:

Men fall from you like rotten fruits, oh, let them perish, for thus they return to your root; so may I, too, O tree of life, that I may grow green again with you and breathe your crown about me with all your budding twigs! peacefully and devoutly, for we are all sprung from the same golden seed! ${ }^{45}$

Becoming green again means participating in the tree of life, as is expressed in the last Beatitude of the Book of Revelation (Rev 22:14). At the end of his epistolary novel, Hölderlin takes up an image from the last book of the Bible, which is also written in the form of a letter, and attempts to use this image to grasp the relationship between man and the divine nature. Here the rise of nature [Aufgang der Natur] and the revelation of the text meet - or, in other words, physis and apokalypsis interpenetrate each other at this important point in Hölderlin's work.

Both Hölderlin's poetry and Hyperion record a disintegration of all of the epoch's guiding motifs, which can be recapitulated as the emptying of religion; but this does not lead to nihilism or to a cynical observation of decline, nor to falling silent. In an analogous way, Hegel does not allow Eleusis to end with the decay of religion or with a definitive judgment having been pronounced against it. After the passage quoted above about the loss of the sacred, he returns to it again and again and even speaks of the "holy night (heil'ger Nacht)" (Eleusis, v. 8o), which is a conscious reference to Hölderlin's poetry,

43 Friedrich Hölderlin, Hyperion and Selected Poems, 13 o.

44 Friedrich Hölderlin, Hyperion and Selected Poems, 133.

45 Friedrich Hölderlin, Hyperion and Selected Poems, 133. 
especially since the word "holy" hardly ever appears in Hegel's work, whereas for Hölderlin "holy" and especially "holy night" 46 are key words.

This leads to the point of departure for Hölderlin's late poems (starting from around 1800): Hölderlin's poetry deals with the loss of the divine; however, this thought is not merely proclaimed but is developed in ever new ways in his poems. As an all-dividing separation of the world of the gods and the world of men, it is an apocalyptic expression of the disjunction that alienates man from society, nature, memory and the future. Beyond this, however, Hölderlin will inquire as to what extent religion itself although caught in the movement of this loss, can nevertheless once again open a new linguistic horizon. In this respect, Hölderlin becomes almost emblematic for Hegel, because to Hegel Hölderlin seems to embody precisely this question. This can be seen in the Phenomenology of Spirit, where at the beginning of The Revealed Religion - as already mentioned - Hegel describes the loss of religion in very similar words as in Eleusis, and in doing so comes close - this is probably the only time in the entire Phenomenology - to poetic language. He then uses the word "However", initiating a reversal which is able to give new meaning to all those expressions of religion that are no longer alive, which he describes as plucked fruits. ${ }^{47}$

\begin{abstract}
However, the young girl who presents us the plucked fruits as a gift is more than the nature that immediately provided them, more than the nature that unfurls into their conditions and elements, into the trees, air, light, etc., while in a higher way she gathers all this together into the gleam of her self-conscious eye and her offertory gesture; just as she is more than that nature, so too the spirit of the fate that provides us with those works of art is more than the ethical life and actuality of that people, for it is the inwardizing-recollecting of the spirit in them that was still alienated $[\ldots]^{48}$
\end{abstract}

It is no longer nature in its immediacy that gives us these fruits, but a person. Hegel seems to be thinking of Hölderlin as summarizing this loss through the "gleam" or the ray of the self-conscious eye and the gesture of giving and, what is more, as offering a language that can become the impetus for a new view of religion characterized by openness. ${ }^{49}$

\footnotetext{
46 Cf. for instance: "But they are, you say, like priests holy to the god of wine, who went from country to country on holy night. (Bread and wine, v. 123 et seq.)

47 It is only after this passage that the conceptual unfolding of The Revealed Religion begins in the Phenomenology.

48 G.F.W. Hegel, The Phenomenology of Spirit. Translated and edited by Terry Pinkard, Cambridge 2018, 432 .

49 I thank Friedrich Kern for this reference. Cf. K. Appel/J. Deibl, Hegel, Hölderlin e l'apertura della "Gottesfrage", in: estetica. studi e richerche 10 (2/2020), 439-478.
} 


\section{Hölderlin's late Poems - the Absence of Holy Names}

Hölderlin's late poems no longer have a secure starting point from which to unfold their subject matter - all that remains is the experience of the loss of the divine, which can be seen as an emblem for all the forms of decay described. But what does this mean regarding the beginning of these poems? The great hymns and elegies such as Heimkunft, Wie wenn am Feiertage ..., Brod und Wein, Patmos, etc., address this loss and begin (regarding their motifs, not regarding their chronology) where Hegel's Phenomenology of Spirit ends, namely with the category of transition - which no longer seeks to attach/affix objective or positive meaning to the ego, the world, God and language, but instead thinks of them as negativity due to their characteristic withdrawal. ${ }^{50}$ In the Science of Logic Hegel will continue this transition as the reversal of being and nothingness, Hölderlin, however, as a vibrating openness, ${ }^{51}$ which he believes he can express through poetic language. Poetry, for which all certainties and "natural" representations have fallen apart, can no longer take its starting point from objects or themes, but must seek to tell, in small steps, how its objects, relationships, directions and meanings are constituted out of this vibrating openness. Each poem is thus also a process of the origination of language.

The poem Heimkunft (Homecoming), written in 1801, can be seen as paradigmatic in this regard. The mention of the absence of holy names expresses the loss of the divine (v. 101) and embeds this loss in the framework of an extensive poem. The end of the long tradition, beginning with Enosh, of naming the name of God, i.e., the holy name, seems to be stated here, even before modern criticism of religion begins to unmask the name of God as a projection, a medium for concealing social power relationships, an exaggerated hypothesis, a meaningless word, etc. But this does not mean that the last word of the poem has been spoken. It ends with the motif of a worry that is peculiar to the poet (or singer), which he cannot disclaim: "Cares like these, whether he likes it or not, a singer / Must bear in his soul, and often, but the others not. (Sorgen, wie diese, muss, gern oder nicht, in der Seele / Tragen ein Sänger und oft, aber die anderen nicht.)" (v. 107 et seq.) In what does this care specifically of the poet consist, as one who lives from a creative relationship with language?52

$5^{\circ}$ Cf. K. Appel, Christianity and a New Humanism, especially: C. Absolute Knowledge and the Body of God, 24-26.

51 I wish to thank Friedrich Kern for this expression.

$5^{2}$ These two final verses are probably crucial to the interpretation of the entire poem. They have remained unchanged in both versions of Heimkunft, the published first version and the revised second version, and were already part of that preliminary stage of the poem, comprised of only its last four verses (v. 105-108). Cf. F. Hölderlin, Sämtliche Werke und Briefe (Münchener Ausgabe Band 1), München/Wien 1992, 319-323, 368-371 und F. Hölderlin, Sämtliche Werke und Briefe (Münchener Ausgabe Band 3), München/ Wien 1993, 177 et seq. 
Heimkunft $t^{53}$ is Hölderlin's last elegy and is addressed "To kindred ones". Apart from M. G., this is Hölderlin's most comprehensive dedication: It no longer refers to individual persons but includes all those who are related to the poet. These are not the people who are part of the same genealogy as he is or who live in his homeland, but rather those who share his poetic concern, who are related to the profession of the poet. A homeland comes about where people are connected to one another, inasmuch as they share the poet's unique concern. Consequently, although the title is probably connected with Hölderlin's two experiences of returning home, from Hauptwil in Switzerland in 18 o1 and from Bordeaux in 1802 , it should not merely be understood as referring to the return to the place of one's childhood. What may be meant by homecoming is to be kept open for the time being. The following considerations offer an overview of the six stanzas of the poem. ${ }^{54}$

I

Drin in den Alpen ists noch helle Nacht und die Wolke,

Freudiges dichtend, sie deckt drinnen das gähnende Tal.

Dahin, dorthin toset und stürzt die scherzende Bergluft,

Schroff durch Tannen herab glänzet und schwindet ein Strahl.

${ }^{5}$ Langsam eilt und kämpft das freudigschauernde Chaos,

Jung an Gestalt, doch stark, feiert es liebenden Streit

Unter den Felsen, [...]

I

Within the Alps it is still bright night and the cloud,

Composing poems full of joy, covers the yawning valley within.

This way, that way, roars and rushes the playful mountain breeze,

Steep down through the fir trees a ray of light gleams and vanishes.

${ }^{5}$ Chaos, trembling with joy, slowly hurries and struggles,

Young in form, yet strong, it celebrates loving strife

Amidst the rocks, $[\ldots]$

53 Cf. F. Hölderlin, Sämtliche Gedichte (Deutscher Klassikerverlag Band 4), 749-752; R. Zuberbühler, Hölderlin: 'Heimkunft', 56-75; M. Heidegger, "Heimkunft / An die Verwandten", in: idem, Erläuterungen zu Hölderlins Dichtung (GA 4), Frankfurt a. M. ${ }^{6}$ 1996, 9-31; idem, Der Fehl heiliger Namen, in: idem, Aus der Erfahrung des Denkens. 1910-1976, 22002, 231-235; B. Liebrucks, "Und", 558-576; W. Groddek, Heimkunft, in: Hölderlin-Jahrbuch. Leben - Werk - Wirken, ed. by J. Kreuzer, Stuttgart/Weimar 2011, 325-327, 335; F. Hölderlin, Sämtliche Werke und Briefe (Münchener Ausgabe Band 3), 177 et seq.; S. Lübcke, Erfüllungspoetiken. Nachleben des ewigen Lebens bei Klopstock, Hölderlin, Rückert, George und den Surrealisten, Berlin 2019, 399-435.

54 All six stanzas consist of 18 verses, "whereby this number is usually clearly divided into $3 \times 3$ distiches", F. Hölderlin, Sämtliche Gedichte (Deutscher Klassikerverlag Band 4), 710 . I use the translation by Keith Holler, cf. M. Heidegger, Elucidations of Hölderlin's Poetry. Translated with an Introduction by Keith Hoeller, New York 2000, 24-31. 
In its first two verses the poem takes us into a valley surrounded by mountains. This is to be noted as pure movement of being drawn in, beginning with "Within (Drin in)" (v. 1) and leading into a "within (drinnen)" (v. 2). As one can see, in the German version there is a slight modification within the movement from "Drin in" to "drinnen", while in English both words can be translated as "within". The adverbs "this way, that way (dahin, dorthin)" (v. 3), which are placed next to each other and separated only by a comma, do not offer any caesura but only a still undetermined oscillation of approaching and moving away. In this pure movement of an aimless roar (v. 3), no places or points of view can yet be established from which the poet could proceed to a description of the surrounding scenery. We enter the poem completely disoriented, taking in the mere indication of movement. We have no choice - especially since here, as in the entire first stanza, there is no one to whose gaze we could entrust ourselves - but to surrender to any movement that the poem offers, which forces us to observe the smallest changes and shifts that occur in the process.

Above the gaping valley a cloud is spread out in the bright night (v. 1 et seq.), which is probably to be seen as an allusion to the description of primordial chaos in Gen 1, where it says: "And the earth was without form, and void; and darkness was upon the face of the deep. And the Spirit of God moved upon the face of the waters." (Gen 1:2). Following Greek mythology, the yawning valley that gapes open in the Alps symbolizes "chaos" (v. 5): The Greek word "chaínein", from which "chaos" is derived, means both "to yawn" and "to gape". Above this chaos hovers the joyfully poetizing, i.e., linguistic cloud, without which the poem could not be written, because at this point there are not yet any speakers in the poem. Language represents a space that precedes the subject and into which it is placed, without language being "producible". The joyfully poetizing cloud stands for this linguisticality unavailable to us, which allows us to access language in the first place. Behind the almost mythical beginning of the poem is the experience of loss (of the self, the world, God), which Hölderlin described in the preceding poems and which does not allow him to begin the poem with a specific subject, but instead makes necessary a description of how we can access language.

The first caesura occurs after the mention of the roar (v. 3); the "and" with which the sentence is continued does not add anything new but can now, in the mere motion into which we were taken, indicate the outline of a direction: "and rushes (und stürzt)" (v. 3). It is not the motion of elevation that occurs at the beginning - who is there that could rise? - but rather the primary movement is that of rushing or falling, a motion indebted to the basic force of gravity and which requires no effort of its own. But it is not falling in the sense of the "(sinful) Fall", which for Hölderlin stands at the beginning and serves to 
characterize man morally. This falling is not yet to be understood anthropologically but is first to be understood as elementary ("steep down (schroff)", v. 4) in two respects: as the movement par excellence that requires no activity of its own, and as a descent from above down to earth, which is depicted as a ray shining down (v. 4). This ray stands for the divine, but this can in no way yet be expressed in human terms; instead, it is something vanishing that cannot be retained. But this is exactly that in which its healing nature consists: There are as yet no forms that are able to catch it, as they would be destroyed in the attempt. The pure motion of roaring has now given way to a first orientation, namely to the motion of rushing or falling. Even though it is still entirely concealed, this introduces referentiality for the first time - the movement of falling becomes a reference to the descent of the divine.

The withdrawal of the divine (the dwindling ray) passes into a first form of temporalization, as the beginning of the following verse shows: "slowly (langsam)" (v. 5) is already to be understood as a temporal determination - in contrast to "still (noch)" (v. 1), which indicates a representation of the primordial origin preceding any temporality (v. 1 et seq.). It can also be stated, based on the inaugural lecture, that the motif of withdrawal is deeply connected with the question of temporality:

Within this experience the world and the self have a radically temporal structure. Thus "time" is not a collection of definable moments within a chronological series, nor a substratum of any event-particles upon which it is based. Time is the detachment that the self experiences in its world-encounter in which it is trying to situate itself within the world. Therefore, every view of the world is a temporal form of detachment. ${ }^{55}$

The word "slowly" introduces a calming effect into the roaring and rushing, which will open the possibility that something durable might also emerge in this joyfully trembling chaos (v. 5). "Slowly" determines the entire fifth verse, which can be seen even more clearly in the German version, where the verse begins with this word: "Chaos, trembling with joy, slowly hurries and struggles (Langsam eilt und kämpft das freudigschauernde Chaos)". The translation by Michael Hamburger preserves the word order here more precisely: "Slowly it hurries and wars, this Chaos trembling with pleasure". ${ }^{56}$ This hurrying is an extension of the motion of falling and gives it a more definite orientation,

55 K. Appel, Christianity and a new Humanism, A. The World as Mirror of the Self and its Shattering-Consciousness, Self-Consciousness, Reason and Spirit in Hegel's Phenomenology of Spirit, 12.

56 Cf. Friedrich Hölderlin: Poems and Fragments. Translated by Michael Hamburger. Fourth Bilingual Edition with a Preface, Introduction and Notes, London ${ }^{4} 2004$. 
which for the first time suggests a form of intentionality. The struggling, which is said to be slow, is no longer the blind rush of chaos, but rather describes chaos as already on the cusp of generating something that will not immediately be swallowed up again.

"Chaos" (v. 5) designates the determining force of the first verses. These hint at a state that has not yet passed into a form of differentiation and clear distinction, which the paradoxical expressions "bright night (helle Nacht)" (v. 1), "slowly hurries (langsam eilt)" (v. 5) and "trembling with joy (freudigschaudernd)" (v. 5) show. The poem is a depiction which, within the undifferentiatedness of the opposites and the hurry of chaos, describes the first emergence of direction ("rushing (stürzen)", "hurrying (eilen)") and finally of "form (Gestalt)". The goal of the first six verses is pronounced in the phrase "young in form (jung an Gestalt)" (v. 6). Even more than the falling and hurrying, the form allows a first lasting formation to become discernible. Therefore, the roar of chaos can afterwards be addressed as a celebration of "loving strife (liebenden Streites)". Now this strife is no longer linked to the destructiveness of being born and devoured, but instead constitutes the joyous quarrel that binds form and matter into one entity. In the entire roaring space of the yawning valley, the first slow, quiet enclaves of formation emerge "Amidst the Rocks (Unter den Felsen)" (v. 7). There chaos is turned into loving strife.

The following verses are characterized by an incipient differentiation of time:

[...] es gärt und wankt in den ewigen Schranken,

Denn bacchantischer zieht drinnen der Morgen herauf.

Denn es wächst unendlicher dort das Jahr und die heilgen

${ }^{10}$ Stunden, die Tage, sie sind kühner geordnet, gemischt.

Dennoch merket die Zeit der Gewittervogel und zwischen

Bergen, hoch in der Luft weilt er und rufet den Tag.

$[\ldots]$ it seethes and shakes in its eternal bounds,

For more bacchantically morning rises within.

For the year grows more endlessly there and the holy

${ }^{10}$ Hours, the days, are more boldly ordered and mingled.

Yet the bird of the thunderstorm notes the time and between

Mountains, high in the air he hovers and calls out the day.

We are still far from the pacific state that would allow for more differentiated forms, but our first glance into the yawning valley grants us the realization that the fomenting and seething chaos is itself caught in "eternal bounds (ewigen Schranken)" (v. 7). Being eternal, these elude human control; at this point no self or subjectivity is present which could set these bounds as such. We rather encounter them amidst the chaos itself, if we attentively observe the 
development presented in the poem. We cannot yet do anything other than merely absorb the language of the poem, especially since no categories of order (such as causation) have yet been established. The fundamental statement about there being limits to chaos, however, enables us to understand how, amidst the apeiron of this chaos presented as a mountainous world, determined limits first emerge; these limits are hinted at by the phrase "young in form (jung an Gestalt)" (v. 6). This process can now be addressed more concretely through the expression "more bacchantically (bacchantischer)" (v. 8) and be linked to a mythological tradition. The bacchanalian is the first cultic response to the ecstatic-chaotic and thus constitutes a continuation of the celebration of the loving strife (v. 6). "For (Denn)" (v. 8) at the beginning of this verse is the first conjunction that introduces a form of cause, effect and explanation. But this is not yet about certain ritual acts ("more bacchantically") and compelling logical deductions ("For", Denn); all these are rather only intuitions, which are merely supposed to make the described event in some way comprehensible.

What is decisive is the mention of the coming of the morning (v. 8). This is the rising of light, which represents the first form of the experience of the divine. As the inaugural lecture explains, for Hegel, too, this is the first configuration of religion. ${ }^{57}$ Hölderlin expresses the primordial differentiation of night and day (Gen 1,3-5), which fundamentally divides the "bright night (helle Nacht)" (v. 1). This will be the starting point for an abundance of temporal determinations, the implementation of which is initiated by the conjunction "For" (v. 9). The latter "For" appears like a joyful continuation of the "For" of the previous verse. It is able to grow infinitely ("For the year grows more endlessly there", v. 9), rising out of the seething and shaking - and preserving the elusive alternation of night and day, without which there would be no growth. We encounter the year (according to which the growth of nature orients itself), the day (which gives man his basic measure of time) and finally the holy hour (as the time of celebration). The days "are more boldly ordered and mingled (sind kühner geordnet, gemischt)" (v. 10), i.e., they are not placed in an abstract, lifeless order. At the end of this section, the "bird of the thunderstorm (Gewittervogel)" - is it the bird of Zeus or the eagle symbolizing the Gospel of John? - is able to lift itself into the air and fly around between the mountain peaks. The bird "notes" (v. 11) the time and "calls out" (v. 12) the day. In front of him a mountain range, a landscape of time with its peaks and abysses in between, spreads out. Where at the beginning of the stanza our gaze was drawn into an alpine valley, now

57 Cf. K. Appel, Christianity and a new Humanism, B. Religion as Loss of the Self - on the Significance of Religion in Hegel's Phenomenology of Spirit, 19. 
a view of the mountains as a landscape opens for the first time. The motif of calling out the day concludes the passage: It has become day. It is precisely at this point that the third section of the first stanza begins, and with "now (jetzt)" (v. 13) it seeks to fix a point from which observations can take their further course:

Jetzt auch wachet und schaut in der Tiefe drinnen das Dörflein

Furchtlos, Hohem vertraut, unter den Gipfeln hinauf.

${ }^{15}$ Wachstum ahnend, denn schon, wie Blitze, fallen die alten Wasserquellen, der Grund unter den Stürzenden dampft,

Echo tönet umher, und die unermeßliche Werkstatt

Reget bei Tag und Nacht, Gaben versendend, den Arm.

Now in the depths within, the little village also awakens and

Fearless, familiar with the high, looks up from under the peaks.

${ }^{15}$ Divining growth, for already, like lightning flashes, the ancient

Waterfalls crash, the ground steaming beneath the falls,

Echo resounds all about, and the immeasurable workshop,

Dispensing gifts, actively moves its arm by day and night.

Starting from this "now" (v. 13), space is configured, following the differentiation of time in the previous section. The first movement goes down into the depths to a village, from which the perspective, like the "growth" (v. 15) it senses ("Divining growth", v. 15), moves upwards again in a first reversal. In the second reversal, lightning and water come down again from above, but they are no longer immediately reflected through a reversal of their movement (as occurred twice before). For the first time the "ground (Grund)" (v. 16) appears, although still steaming and not solid. But its discovery makes the landscape become the sound space for a reverberating echo (v. 17). There is as yet no one speaking to make the echo the echo of a voice; prior to this, the landscape becomes a sound body in which later words, voices and language can sound and resound in manifold ways. The seething and shaking chaos has become the demiurgical "workshop (Werkstatt)" (v. 17) of nature, inserted into the initial order of "day and night" (v. 18), its immensity removed from man: "The first stanza has not yet spoken of man. It offers the great picture of a nature that is experienced as immeasurable workshop when it is still demiurgical."58 The elementary dimensions of space - vertically from above and from below and horizontally as the "ground" (v. 16) - having been constituted, now begins the motion of sending "gifts (Gaben)" (v. 18), the recipients of which are constituted in the second stanza. 
II

Ruhig glänzen indes die silbernen Höhen darüber,

${ }^{20}$ Voll mit Rosen ist schon droben der leuchtende Schnee.

Und noch höher hinauf wohnt über dem Lichte der reine Selige Gott vom Spiel heiliger Strahlen erfreut.

Stille wohnt er allein und hell erscheinet sein Antlitz,

Der ätherische scheint Leben zu geben geneigt,

${ }^{25}$ Freude zu schaffen, mit uns, wie oft, wenn, kundig des Maßes,

Kundig der Atmenden auch zögernd und schonend der Gott

Wohlgediegenes Glück den Städten und Häusern und milde

Regen, zu öffnen das Land, brütende Wolken, und euch,

Trauteste Lüfte dann, euch, sanfte Frühlinge, sendet, ${ }^{30}$ Und mit langsamer Hand Traurige wieder erfreut,

Wenn er die Zeiten erneut, der Schöpferische, die stillen

Herzen der alternden Menschen erfrischt und ergreift,

Und hinab in die Tiefe wirkt, und öffnet und aufhellt,

Wie ers liebet, und jetzt wieder ein Leben beginnt,

${ }^{35}$ Anmut blühet, wie einst, und gegenwärtiger Geist kömmt,

Und ein freudiger Mut wieder die Fittige schwellt.

II

Meanwhile the silvery heights gleam peacefully above, ${ }^{20} \mathrm{Up}$ there the luminous snow is already full of roses.

And still higher up, above the light, dwells the pure

Blissful god rejoicing in the play of holy rays.

Silently he dwells alone, and brightly shines his countenance,

The aetherial one seems inclined to give life

${ }^{25}$ To create joy, with us, as often, when, knowing the measure, Also knowing those who breathe, hesitant and sparing, the god

Sends true good fortune to towns and houses and gentle

Rain to open the land, brooding clouds, and then you,

Dearest breezes, you gentle springtimes,

${ }^{30}$ And with patient hand brings joy again to those who mourn,

When he renews the seasons, the creative one, refreshes

And seizes the silent hearts of aging men,

And works down to the depths, and opens and brightens up,

As he loves to do, and now once again a life begins,

${ }^{35} \mathrm{Grace}$ blooms, as once, and present spirit comes,

And a joyous courage spreads its wings once more.

The second stanza describes a calm mountainous world. The word "peacefully (ruhig)" (v. 19) summarizes the entire previous movement in one term. Again here, Michael Hamburger closely follows the word order of the original German: "Quiet, meanwhile, above, the silvery peaks lie aglitter" (v. 19).

At the beginning of the stanza, the view is directed to the heights of the mountains, which at dawn are messengers of the approaching day (v. 19). ${ }^{59}$ That 
which in the first stanza had to struggle to wrest itself away from the roaring, seething and shaking of chaotic forces is now calmly displayed by the peaks. The glittering heights to which our gaze wanders become the reference to an elevation that transcends them, leading beyond the "light" (v. 21) to reach a pure, blessed God (v. 21 et seq.). His dwelling above the light is taken up again in the next verse in the phrase "Silently he dwells alone" (v. 23). The first of the two phrases that speak of God's dwelling (v. 21 et seq.) is still part of a great soaring movement. This movement begins in the first stanza with the fall and leads from hurry to the village's unhurried gaze, which first wanders upwards and, after a reversal with lightning and springs of water, comes down again to reach ground for the first time. Starting from there and transcending the shining mountain heights, in the second stanza it reaches the God above the light.

With the word "silently (stille)" (v. 23), which opens the next verse and thus the second phrase on the dwelling of God, this movement has now concentrated itself in one word and become calm. God is no longer the transcendens of an elevating movement towards an ever greater beyond, but rather stands as a figure ("form (Gestalt)", v. 6) before the observer. With God's appearing as a figure, man will now also be able to enter the poem.

It is the "countenance (Antlitz)" (v. 23) of God which appears. This revelation goes beyond the first configuration of a form in the sixth verse ("young in form (jung an Gestalt)") and brings into focus the possibility of encounter. Like the entire subsequent development, such an encounter depends on the gifts of this God who seems inclined to "give life" (v. 24). The gift-giving impulse of demiurgical nature, pictured as an immeasurable workshop (v. 18), culminates in the gift of life; the description and development of this motif extends through the 36 th verse, i.e., to the end of the stanza. In God's movement of gifting, man too comes into being - as a breathing creature (v. 26). God, on the other hand, appears "knowing the measure (kundig des Maases)" (v. 25). This characterization does not appear unheralded; chaos had already shown itself to be caught in "eternal bounds" (v. 7) and had allowed a first living order in time to arise ("ordered and mingled (geordnet, gemischt)", v. 10). This order now becomes a measure which has nothing to do with a technical scale of measurement, but instead indicates ratios, i.e., corresponding quantities. The phrase "knowing the measure", which appears at the end of verse 25 and refers to God, is taken up again in a similar way at the beginning of the next verse, where it says "knowing those who breathe (kundig der Athmenden)" (v. 26). The breath of life, which is given to man, finds its measure in divine measure; it is in harmony with the divine breath, the Spirit. Man is thus the embodiment of a fragile measure which has arisen out of roaring chaos. Nature and man can indeed be described in parallel (concerning their passing and rising), but man can no longer be embodied by nature. Thus, the poem complements the sending 
of gentle springtimes (v. 29) as an image of nature's repeated renewal with the slowly rejoicing mournfulness (v. 3o) and the "silent / hearts of aging men (stillen / Herzen der alternden Menschen)" being refreshed and seized (v. $3^{1}$ et seq.). As men age they fall out of nature's cyclical process of renewal. Their mortality is not veiled; rather, man who begins aging from birth is to be led into joy ${ }^{60}$ and openness (v. 33), and "Grace (Anmuth)" is to blossom over him (v. 35). This grace is rooted in the indisposability of the mortal human essence, which finds no equivalence in nature's renewing process of generation. Rather, it is the embodiment of a fragile measure into which the movement of nature has been concentrated and which - inaccessible to any form of self-production can only be understood as spiritual (v. 35).

The guiding concept of the second stanza is the silence that is expressed relative to the dwelling of God and to the hearts of men (v. 31 et seq.), which are dependent on him. The silent hearts' dependence on God is indicated by the adjectival (and thus not independent) use ("silent hearts"), which does not let that silence stand freely - unlike the adverb "silently", which characterizes the dwelling of God. Moreover, "silent" and "hearts", although united by an enjambment, are joined through rupture: "silent / hearts of aging men" (v. 31 et seq.). If one examines silence in Hölderlin's poetry, starting from its first appearances, it becomes clear that, as the antithesis to falling silent, it is that from which words emerge in the first place. Thus, after introducing man as silently participating in God's silence, the third stanza will now look at man's initial linguisticality:

III

Vieles sprach ich zu ihm, denn, was auch Dichtende sinnen

Oder singen, es gilt meistens den Engeln und ihm;

Vieles bat ich, zu lieb dem Vaterlande, damit nicht

${ }^{40}$ Ungebeten uns einst plötzlich befiele der Geist;

Vieles für euch auch, die im Vaterlande besorgt sind,

Denen der heilige Dank lächelnd die Flüchtlinge bringt,

Landesleute! für euch, [...]

III

Much I spoke to him, for whatever poets meditate

Or sing, it mostly concerns the angels and him;

Much I asked for, for love of the fatherland, lest

${ }^{40}$ Unbidden one day the spirit might suddenly fall upon us;

Much also for you, who have cares in the fatherland,

To whom holy thanks, smiling, brings the fugitives,

Countrymen! for you, [...]

6o For Heidegger, joy or "the joyful" is the central word of the poem. See M. Heidegger,

Elucidations of Hölderlin's Poetry, 34 . 
At the end of the first stanza, the mountainous landscape had developed into a sound space (v. 17) that was ready to hear the silence of God, before whose face the breathing men appeared with silent hearts. God as "the creative one (der Schöpferische)" (v. 31) had caused men to open up (v. 33) and allowed life to begin (v. 34). The sphere of the living, which had developed in the course of the second stanza, is now filled with the coming of the present spirit (v. 35). Man's linguisticality corresponds to this spiritual dimension. This is the starting point of the third stanza, which begins with the words "Much I spoke to him" (v. 37). In these words - for the first time in this poem - we encounter a self. This self is not presented in its self-sufficiency, but instead in its relation to God. As the first form of language, prayer and poem appear as indistinguishable: "whatever poets meditate / Or sing (was auch Dichtende sinnen / Oder singen)" is "mostly" (v. 37 et seq.) addressed to God ("him", v. 38) and the angels.

The first section of the stanza is marked by multiplicity. The first three distichs each begin with "Much" (v. 37, 39, 41), which distinguishes them from the pure unity of silence of the second stanza. As soon as language appears as human language, it is caught in the ambivalence of a multiplicity. On the one hand, this multiplicity represents its openness and its inexhaustibly referential nature, but, on the other hand, also indicates a form of distraction, which can no longer be concentrated in a word like "silently" (v. 23) or "peacefully" (v. 19). The ego lacks the necessary means of expression for this when language first appears. The conjunction "whatever" steps into this deficiency with the recapitulatory force of logical reflection: "for whatever poets meditate / Or sing, it mostly concerns the angels and him" (v. 37 et seq.). ${ }^{61}$ At this point we again encounter the self-reflexive nature of poetry, which is evident from Hölderlin's first poems, and it is once more accompanied by the indistinguishability of poetry and prayer. On this basis we have to consider three motifs:

1) The structure described is reminiscent of the biblical story of Abel/ Seth/Enosh, which in the Holy Scriptures reflects the coming-to-language of the name of God: While Cain is immediately presented as speaking and this linguisticality leads into Lamech's boastful and deterrent heroic song, the coming-to-language of Enosh, who is the first to mention the name of God, is connected to a long history of experiences that go even as far as violent death. Abel himself is still mute; only his blood will cry out to God after his death. Eve is able to express that Seth will become a substitute for Abel, and through the mention of the name of God the figure of Enosh passes into prayer.

61 Bruno Liebrucks says about this: "The words that follow 'for [denn]' give an explanation of poetry itself within poetry, which is to be read as a second reflection, since this is how its poetic conception is expressed." B. Liebrucks, “Und”, 566. 
2) We encounter three basic linguistic forms of poetry and prayer after the first occurrence of language in the following three distichs (v. 39-45): plea (v. 39), thanks (v. 42) and praise (v. 44). The first of these is the plea for the capacity to endure the revelation of God: "lest / Unbidden one day the spirit might suddenly fall upon us" (v. 39 et seq.). It thus represents a connection between the shining and fading of the ray from the first stanza (v. 4) and the adjectives "hesitant and sparing (zögernd und schonend)", which in the second stanza immediately precede the appearance of God (v. 26), as well as the adverb "gentle (mild)" (v. 27) - all these phrases revolving around the fact that the divine can reveal itself only in its withdrawal. In poetry, therefore, the question arises as to how the appearance of God can be grasped, and yet how his absence, which cannot be ignored but requires verbalization, can also be grasped. ${ }^{62}$ The poet's concern becomes discernible for the first time.

3) While in the first two stanzas of the poem we were still observers who were granted an insight into the roar of chaos and who were briefly allowed to participate in the eagle's view of the temporal landscape of the mountains and the rising gaze of the village (v. 13), from now on, as the first two verses of the third stanza show, the lyric self appears as reflective self. The poem, which hitherto was written in the present tense, changes now to the preterite tense, indicating a distance with regards to the immediate presence and thus to a loss: "spoke" (v. 37), "asked" (v. 39), "rocked" (v. 43), "sat" and "praised" (v. 44). The self no longer has a homeland, but instead finds itself en route into the unknown. ${ }^{63}$ Heidegger says of this new movement of searching that it cannot be brought to rest by finding anything. ${ }^{64}$ "Homecoming", let this be said in advance, will not mean a return to a definite place of arrival established in the course of the text.

[...] indessen wiegte der See mich,

Und der Ruderer saß ruhig und lobte die Fahrt.

${ }^{45}$ Weit in des Sees Ebene wars Ein freudiges Wallen

Unter den Segeln und jetzt blühet und hellet die Stadt

62 Cf. the last verse of Hölderlin's poem Dichterberuf: "Furchtlos bleibt aber, so er es muß, der Mann / Einsam vor Gott, es schützet die Einfalt ihn, / Und keiner Waffen brauchts und keiner / Listen, so lange, bis Gottes Fehl hilft." "Fearless yet, if he must, man stands, and lonely / Before God, simplicity protects him, no / Weapon he needs, nor subterfuge / Till God's being not there helps him." (v. 61-64), translated by Christopher Middleton, in: Friedrich Hölderlin, Hyperion and Selected Poems, ed. by Eric L. Santer, New York 1994, 152-157.

63 Cf. K. Appel, Christianity and a new Humanism, A. The World as Mirror of the Self and its Shattering - Consciousness, Self-Consciousness, Reason and Spirit in Hegel's Phenomenology of Spirit, 11-19.

64 Cf. M. Heidegger, Elucidations of Hölderlin's Poetry, 33. 
Dort in der Frühe sich auf, wohl her von schattigen Alpen

Kommt geleitet und ruht nun in dem Hafen das Schiff.

Warm ist das Ufer hier und freundlich offene Tale,

${ }^{50}$ Schön von Pfaden erhellt grünen und schimmern mich an.

Gärten stehen gesellt und die glänzende Knospe beginnt schon,

Und des Vogels Gesang ladet den Wanderer ein.

Alles scheinet vertraut, der vorübereilende Gruß auch

Scheint von Freunden, es scheint jegliche Miene verwandt.

[...] meanwhile the lake rocked me,

And the boatman sat calmly and praised the journey.

${ }^{45}$ Far out on the surface of the lake was One joyous swell

Beneath the sails, and now the town blooms and brightens

There in the dawn, and the boat is safely guided

From the shady Alps and now rests in the harbor.

Warm is the shore here and friendly the open valleys,

${ }^{50}$ Beautifully lit up with paths, gleam verdantly toward me.

Gardens stand together and already the glistening bud is beginning,

And the bird's song invites the wanderer.

All seems familiar, even the hurried greetings

Seem those of friends, every face seems a kindred one.

"Meanwhile" (v. 43) introduces a break. At this point the lyric self appears "pictorially in the song"65, becomes part of the landscape described and moves within it. When this self first appears, it does not reside in a tranquil dwelling but is on a journey between the Alps and the city of Lindau. ${ }^{66}$ Since in the first stanza (cf. v. 1), the Alps have represented the divine realm, the journey from the shady mountains to the bright city must also be understood as a journey between the divine and the human realm:

The journey across Lake Constance is the journey from the divine realm of the Alps to the human realm of the city of Lindau, the gateway to the homeland. As the connection, it is uninjured being, which is both divine realm and human homeland. ${ }^{67}$

But how can the connection between the geographic and metaphysicalreligious topos of the journey be understood? We are confronted with a new approach, for which Hölderlin opted in his poetry from around 1800 onwards.

65 B. Liebrucks, "Und", 566.

66 As the inaugural lecture points out, all "texts of fundamental importance to Europe (the story of Abraham, the Odyssey, the Aeneid)" are shaped by this primacy of the journey (K. Appel, Christianity and a new Humanism, A. The World as Mirror of the Self and its Shattering - Consciousness, Self-Consciousness, Reason and Spirit in Hegel's Phenomenology of Spirit, 11 ).

67 B. Liebrucks, "Und", 566 et seq. 
He repeatedly takes real places, mountains, rivers, cities and islands as the starting points of his poems (Heidelberg, Am Quell der Donau, Der Ister, Stuttgart, Patmos ...) and unfolds his poetry from these locations. The background to this shift is the experience, described in the previous chapter, that the immediate meanings of all basic words and guiding ideas have disintegrated and that poetry can no longer presuppose them or build upon them. Every poem is now faced with the task of forming a new sphere, in which relationships, directions and structures of meaning slowly begin to reemerge. Each poem can thus also be seen as a journey into language. Of course, it would be a mere abstraction to think that a poem could start from scratch and reinvent language. In the first two verses of Homecoming, Hölderlin says that "the cloud, / Composing poems full of joy, covers the yawning valley within" (v. 1 et seq.). From the very beginning, we partake in the journey into language, but we do not have complete control and sovereignty over it. So what does Hölderlin do? He now chooses factually pre-given entities - real geographical locations - as his starting point and begins to depict these. In the context of this depiction, it is important to comprehend how the smallest changes in the landscape or shifts in perspective provoke a corresponding increase in the complexity of linguistic expression.

Geographically, the journey represents a spatial approach to the homeland, which passes from the lake (v. 43-48) to the land (v. 49-54) and is characterized by a welcoming gesture regarding the hiker: "friendly the open valleys" crossed by paths (v. 49 et seq.), the inviting song of the birds (v. $5^{2}$ ), a feeling

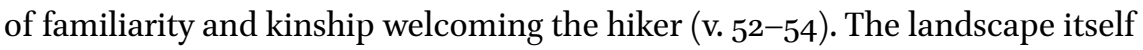
becomes a welcoming salutation - modeled on the gift-giving gesture of the blessed God who had constituted man as a linguistic being in the first place. However, this initial linguisticality had not yet become apparent in any concrete situation. The question will arise as to whether the journey described here and the region presenting itself amicably, in which the poet himself becomes a part of the picture (starting v. 43), will also be able to open for him a new linguistic horizon.

The fourth stanza can be divided into three sections of equal length: the first section (v. 55-6o) addressing the question of opening a new linguistic horizon, the second (v. 61-66) and the third (v. 67-72) each indicating a certain direction.

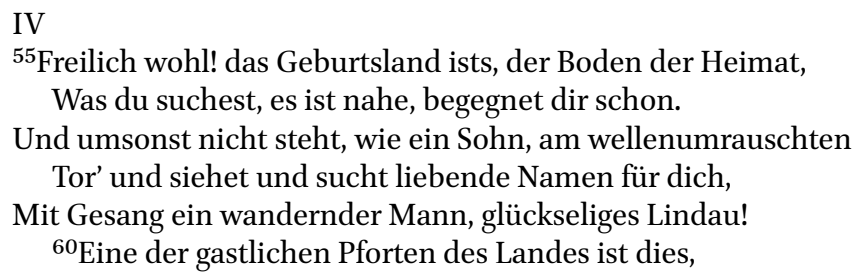


IV

${ }^{55} \mathrm{But}$ of course! It is the land of your birth, the soil of your homeland,

What you seek, it is near, already comes to meet you.

And not in vain does he stand, like a son, at the wave-washed

Gate, and sees and seeks loving names for you,

With his song, a wandering man, blessed Lindau!

${ }^{60}$ This is one of the land's hospitable portals,

The first two verses seem self-contained. The ground "steaming beneath the falls" (v. 16) has solidified into the "soil of your homeland" (v. 55). It seems that the land of birth and the soil of the homeland are what is sought in the following verse: "What you seek, it is near, already comes to meet you" (v. 56) But how do the following verses bring about this encounter? Someone stands at the gate of home "like a son" (v. 57) and is overwhelmed by the hospitable welcome (v. 6o). However, he is not the son who has found his way back to his own, to his homeland, but he is like a son and thus remains the guest, a man who seeks (v. 58) and wanders (v. 59). In the second mention of a search ("and seeks loving names for you", v. $5^{8}$ ), it becomes clear that its deeper motivation is not directed at the soil of the homeland but at naming, language and song. What previously looked like the happy arrival in the homeland reveals itself rather as the inauguration of an even more fundamental search for names for the native places that can correspond to the experience of the joy of the reception. It is the search for a "song" (v. 59) that can rise on the newly acquired ground.

Reizend hinauszugehn in die vielversprechende Ferne, Dort, wo die Wunder sind, dort, wo das göttliche Wild

Hoch in die Ebnen herab der Rhein die verwegene Bahn bricht,

Und aus Felsen hervor ziehet das jauchzende Tal,

${ }^{65}$ Dort hinein, durchs helle Gebirg, nach Komo zu wandern,

Oder hinab, wie der Tag wandelt, den offenen See;

Aber reizender mir bist du, geweihete Pforte!

Heimzugehn, wo bekannt blühende Wege mir sind,

Dort zu besuchen das Land und die schönen Tale des Neckars,

${ }^{70}$ Und die Wälder, das Grün heiliger Bäume, wo gern

Sich die Eiche gesellt mit stillen Birken und Buchen,

Und in Bergen ein Ort freundlich gefangen mich nimmt.

Enticing us to go out into the much-promising distance,

There, where the wonders are, there, where the divine wild game,

High up the Rhine breaks his daring path down to the plains,

And forth from the rocks the jubilant valley emerges,

${ }^{65}$ In there, through bright mountains, to wander to Como,

Or down, as the day changes, to the open lake;

But you are more enticing to me, you consecrated portal!

To go home, where the blossoming paths are known to me, 
There to visit the land and the beautiful valleys of the Neckar,

${ }^{70}$ And the forests, the green of holy trees, where the oak

Likes to stand amidst silent birches and beeches,

And in the mountains a place, friendly, takes me captive.

The arrival in the "land of your birth" (v. 55) immediately passes into a movement spanning two directions, that of going out (v. 61) and that of going home (v. 68), and brings with it a further structuring of the landscape. Their parallel structure ("Enticing to go out ...", v. 61 - "But ... more enticing ... / To go home", v. 67 et seq.) makes it clear that they are not to be considered as isolated and separate from each other. If one takes the fourth stanza as a whole, it becomes apparent that the stanza, which explicitly addresses the topic of the homeland for the first time, carries at its center the idea of leaving. The passages on the homeland (v. 55-6o and v. 67-72) frame the part that deals with going out into the "much-promising distance" (v. 61). But what is it that the distance promises?

The motif of the valley, which is crucial to the poem, allows one to guess in which direction the movement connected to this going out into the distance could proceed. The yawning valley (v. 2) was that which swallows up while generating chaotically. Having been calmed, it became a friendly open valley (v. 49), from whose openness the "jubilant valley" (v. 64) could develop, having become language and poetry (the valley "jubilates"). It was transformed from a mythological valley into a valley as a geographical entity and, ultimately, into a linguistic-poetic valley. In the poetry emerging from this movement, an echo of the initially seething forces of chaos ("yawning valley"), as well as of the actual geographical localization ("friendly open valley"), thus resounds. ${ }^{68}$ The river is addressed as "divine wild game" (v. 62 et seq.), which indicates that we are no longer dealing solely with geographical entities, but also with poetic ones. Plain, river, rock, valley, mountain and lake, however, are not images that stand for other entities which reveal their true meaning. What is decisive is rather the transition taking place here: As elements of the landscape merge into poetry, an oscillation of space and language, place and word, landscape and poetry, arises. In this vibrating openness a new linguistic horizon can unfold, which corresponds to this going out into the promising distance, "where the wonders are" (v. 61 et seq.). Conversely, it is only in this opening of language that a homeland exists.

68 Bruno Liebrucks himself summarizes going out into the distance as the path of poetry: "But beyond that, it is not a matter of the journey of a man but of poetry, in which the Rhine is the divine game (verse 62)." B. Liebrucks, "Und", 568 . 
V

Dort empfangen sie mich. O Stimme der Stadt, der Mutter!

O du triffest, du regst Langegelerntes mir auf!

${ }^{75}$ Dennoch sind sie es noch! noch blühet die Sonn' und die Freud' euch,

O ihr Liebsten! und fast heller im Auge, wie sonst.

Ja! das Alte noch ists! Es gedeihet und reifet, doch keines Was da lebet und liebt, lässet die Treue zurück.

Aber das Beste, der Fund, der unter des heiligen Friedens

${ }^{80}$ Bogen lieget, er ist Jungen und Alten gespart.

Törig red ich. Es ist die Freude. Doch morgen und künftig Wenn wir gehen und schaun draußen das lebende Feld

Unter den Blüten des Baums, in den Feiertagen des Frühlings

Red' und hoff' ich mit euch vieles, ihr Lieben! Davon.

$\mathrm{V}$

There they welcome me. O voice of the town, of my mother!

O you touch me, you stir up what I learned long ago!

${ }^{75}$ Yet they are still the same! Still the sun and joy blossom for you,

$\mathrm{O}$ you dearest ones! And almost more brightly in your eyes than before.

Yes! Old things are still the same! They thrive and ripen, yet nothing

Which lives and loves there abandons its faithfulness.

But the best, the real find, which lies beneath the rainbow ${ }^{80} \mathrm{Of}$ holy peace, is reserved for young and old.

I talk like a fool. It is joy. Yet tomorrow and in the future

When we go outside and look at the living fields,

Beneath the tree's blossoms, in the holidays of spring,

Much shall I talk and hope with you about this, dear ones!

The fifth and sixth stanzas represent the climax of the poem. On the one hand, this shows in the salutatory address of the "dearest" (v. 76 ), which now explicitly addresses those already addressed in the dedication (the "kindred ones"), among whom the wanderer has now arrived. Thus, the poem has now caught up with those to whom it is dedicated: "There they welcome me." (v. 73) On the other hand, the only enjambement (v. go et seq.) that ties two stanzas together also points to the culmination of the poem.

The final part begins with a pause, in which we encounter the erratic sentence: "There they welcome me." (v. 73) It denotes the short period of uncertainty before the joyous embrace of reunion. The poet is now welcomed home and, as the first section of the stanza (v. $73^{-78)}$ suggests, he can grasp this through images of his childhood and thus of the past. The city's motherly reception (v. 73) is the first voice that once opened his ear and now opens it to his homeland. Finally he is able to say: "Yes! Old things are still the same! (Ja! das Alte noch ists!)" (v. 77) This has just as little to do with pathos or regression as the poem has anything to do with homeliness; it rather reminds us of the miracle (and this is not to be understood merely in a figurative sense) of how 
the landscape in which we grew up and the people who cared for us brought us to language. This is what the poet, returning home and warmly received, remembers; but after the first section of the stanza, this memory immediately leads to a far-reaching question: Can returning to the place of one's own coming-to-language once again lead to the opening of language horizons? Or more generally: What allows language to emerge anew and prevents us, who have long since encountered language, from falling silent?

Hölderlin introduces this turnaround with a "But" (v. 79): "But the best, the real find, which lies beneath the rainbow / Of holy peace, is reserved for young and old. (Aber das Beste, der Fund, der unter des heiligen Friedens / Bogen lieget, er ist Jungen und Alten gespart.)" (v. 79 et seq.) The searching movement of the fourth stanza $(v .56,58)$, mentioned twice and which does not end with the arrival in the homeland but represents a search for language, is now answered by a "find", which as "the best" (v. 79) is capable of even exceeding the joy of the return to the native world. Even though the place of this "find" (v. 79) can be named - it is located under the sacred rainbow, the connective function of the bow being expressed through the enjambment (v. 79 et seq.) - it is saved for young and old, i.e., it cannot be taken possession of, it remains stored and thereby withdrawn and inexhaustible. Heidegger particularly emphasizes this in his interpretation and reads "the best" and the "find" (v. 79) as the secret of "becom[ing] at home within a nearness to the origin" 69 :

The nearness to the origin is a nearness which still holds something back in reserve. It withholds the most joyful. It preserves and saves it for those who are coming; but this nearness does not take away the most joyful, it only lets it appear precisely as saved. ${ }^{70}$

Poetry, which itself is never immediate descriptive language, has the task of protecting its origin from any attempt at appropriation:

In order therefore that the reserving nearness to the most joyful may remain protected, the poetic word must take care not to hasten by or to lose that which sends its greeting out of the joyful, which sends its greeting as the self-reserving. ${ }^{71}$

The rainbow of peace (des Friedens Bogen) seems to be a reference to the biblical story of God's covenant with creation, which was saved from the flood, the waters of chaos (cf. Gen 9:8-17). Hölderlin takes up this image of a connection between heaven and earth again in Patmos, where he says: "Under

\footnotetext{
69 M. Heidegger, Elucidations of Hölderlin's Poetry, 43.

70 Ibid.

71 Ibid., 44.
} 
a thundering sky / His sign is silent. (Still ist sein Zeichen / Am donnernden Himmel.)" (Patmos, v. 203 et seq.). Moreover, the image pays homage to the Peace of Lunéville between France and Austria in 1801, which, for Hölderlin, was associated with great hope. ${ }^{72}$

In the homeland, which is connected to return and arrival, a "find", an act of finding, actually takes place, but it encounters an empty place that cannot be (re)appropriated (v. 79 et seq.). Let us now look at the dynamics emanating from this: The mood of the stanza remains joyful (v. 81), but what changes is the perspective: Introduced with a "Yet (Doch)" (v. 81), the view turns from the past (v. 73-78) to the future of tomorrow and beyond ("Yet tomorrow and in the future", v. 81). Again, the movement of walking (v. 82) commences, and with it the new capacity to see with a living perception ("When we go outside and look at the living fields, / Beneath the tree's blossoms", v. 82 et seq.). The holidays in spring (v. 83) - are they nature-related festivals, is it Easter? - draw our gaze into the distance and go hand in hand with the hope that the poet might also find a new way to speak and express himself through the richness of multiplicity ("in the holidays of spring, / Much shall I talk and hope with you about this, dear ones!", v. 83 et seq.). It is not nature alone that sets language into motion; the poet hopes that the community of "dear ones" (v. 84) can also become a new linguistic community, as the dedication of the poem to "kindred ones" suggests. "Much" (v. 84), describing what the poet has to say and also the object of his hope, leads on to the third section of the fifth stanza, which likewise begins with "Much" (v. 85) and then merges into the sixth stanza:

${ }^{85}$ Vieles hab' ich gehört vom großen Vater und habe Lange geschwiegen von ihm, welcher die wandernde Zeit

Droben in Höhen erfrischt, und waltet über Gebirgen

Der gewähret uns bald himmlische Gaben und ruft

Hellern Gesang und schickt viel gute Geister. O säumt nicht, ${ }^{90}$ Kommt, Erhaltenden ihr! Engel des Jahres! und ihr,

VI

Engel des Hauses, kommt! in die Adern alle des Lebens,

Alle freuend zugleich, teile das Himmlische sich!

Adle! verjünge! damit nichts Menschlichgutes, damit nicht

Eine Stunde des Tags ohne die Frohen und auch

${ }^{95}$ Solche Freude, wie jetzt, wenn Liebende wieder sich finden,

Wie es gehört für sie, schicklich geheiliget sei.

72 Cf. J. Schmidt (ed.), Hölderlin, 751. 
${ }^{85}$ Much have I heard about the great father and have

Long kept silent about him, who refreshes wandering time

In the heights above, and reigns over mountain ranges,

Who will soon grant us heavenly gifts and call

For brighter song and send many good spirits. O do not delay,

${ }^{90}$ Come, you preservers! Angels of the year, and you,

VI

Angels of the house, come! Into all the veins of life,

Rejoicing all at once, let the heavenly share itself!

Ennoble! Renew! So that nothing that's humanly good, so that not a

Single hour of the day may be without the joyful ones and that also

${ }^{95}$ Such joy, as now, when lovers are reunited,

As it should be, may be fittingly hallowed.

"Much" (v. 85) occurs again at the beginning of a verse analogous to the third stanza, where language first appeared. In both places, there is reference to language and to God:

Much I spoke to him (v. 37)

Much shall I talk and hope with you about this, dear ones (v. 84).

In contrast to the third stanza, however, the poet does not begin by addressing God; rather, where just a moment ago there was talk of the hope of returning to language (v. 83 et seq.), now there is listening and long silence (v. 85 et seq.). The poet has heard much of God and has remained silent about him for a long time. Here, the ambivalence of "much", which was already present in the word's first appearance, must be noted. It might indicate the abundance of the many witnesses whose life and word tell of God, but it might also be the scattered multiplicity of church traditions, theologies and art that can no longer find a focal point and that no longer speak from silence.

At this point, we must consider two analogies and the resulting shifts within the poem. Firstly: Listening and silence lead to a relative clause ("have / Long kept silent about him, who refreshes wandering time ...", v. 85 et seq.), which then speaks broadly and hymnically about God and passes into a call to praise. This call to praise is even addressed to the angels, who bridge the transition from the fifth to the sixth stanza (v. go et seq.). As in the second stanza, God is spoken of as a giver who grants "heavenly gifts" (v. 88), calls for "brighter song" (v. 88 et seq.) and sends "many good spirits" (v. 89). Once again there is talk of angels ("angels of the year", "angels of the house", v. go et seq.). However, this hymnic talk about God remains inserted within a relative clause and within an imperative, but without - as was still the case at the beginning of the third 
stanza - passing into prayer. It does not change into an invocation of the name of God but leads (starting from v. 97) into radical questioning. Secondly, similar to the immediate return of a joyful mood after the "find" (v. 79) that was saved for young and old and did not lead to possession (v. 79 et seq.), the poem continues in a joyful manner after the mention of the long silence concerning God. However, it is almost concealed that this silence no longer leads to an invocation of God. This joy has now become ambivalent.

Speaking about the works of God and about what he sends mankind might also be part of something learned long ago that now reawakens in the homeland (v. 74). It ends with the image of the sanctification of the joy of the lovers' reunion (v. 94-96), which in the poem, however, does not remain a yearning but takes place "now" (v. 95). The community of "kindred ones" from the dedication, which turns out to be the hoped-for new linguistic community (v. 84), is now completed in the loved ones' finding each other. This is an image of a perfect relationship in the homeland, of comprehensive relationality and integration, in which nothing remains unrelated. But where this unity is most closely knit together, a fundamental question is voiced:

Wenn wir segnen das Mahl, wen darf ich nennen, und wenn wir Ruhn vom Leben des Tags, saget, wie bring ich den Dank?

Nenn ich den Hohen dabei? Unschickliches liebet ein Gott nicht, ${ }^{100} \mathrm{Ihn} \mathrm{zu}$ fassen, ist fast unsere Freude zu klein.

Schweigen müssen wir oft; es fehlen heilige Namen, Herzen schlagen und doch bleibet die Rede zurück?

When we bless the meal, whom shall I name and when we Rest from the life of day, tell me, how shall I give thanks?

Shall I name the high one then? A god does not love what is unfitting, ${ }^{100}$ To grasp him, our joy is almost too small.

Often we must be silent; holy names are lacking, Hearts beat and yet talk holds back?

The hymnic enumeration of the gifts and works of God, which are described in the fifth and sixth stanzas and which make order (v. 96) and fellowship possible, cannot guarantee that God himself can still be addressed. The poem then turns to the question about him that manifests itself as a question concerning the name ("Whom shall I name", v. 97, and even more emphatically "Shall I call the high one then?", v. 99) and language ("How shall I give thanks?", v. 98, and "And yet talk holds back? (und doch bleibet die Rede zurück?)", v. 102). The difficulty of such a search for names and language does not arise unheralded (v. $5^{8}$ et seq.). While it already smoldered in the poem but was still obscured by the joy of the prevailing mood, it breaks through at this point and expresses 
itself clearly and soberly in just a few sentences. The search for names and language obviously fails at its point of culmination, i.e., the naming of the name of God: Sacred names are lacking and speech lags behind (v. 101 et seq.). It would however be premature to declare this absence the irrevocable end of the invocation of the name of God and to seal the silence of speech, for in the word "almost" ("To grasp him, our joy is almost [ fast] too small", v. 100) a small gap opens up which may render further development possible. It is the same "almost" that occurs at the beginning of Mnemosyne, where it says: "A sign we are, without interpretation / Without pain we are and have almost / Lost language in the foreign land." (Mnemosyne, Entwurf, v. 1-3) At this point we must counter two reductive interpretations of Hölderlin's poem: On the one hand, the poem can no longer be understood as embedded in a religious "homeland"; but, on the other hand, it cannot simply be understood as a journey into atheism either, since both variants are unable to endure the dynamics this poem draws into play between joy and interrogation, homeland and foreign land, prayer and loss of the name of God. Both religion and atheism would dismiss as already solved that question whose essence Hölderlin tries to approach.

This also has ramifications regarding the theme of the purpose of man, which is emphasized by the change from "I" to "we" (starting from v. 97) that takes place precisely at this point. This theme permeates the entire poem, beginning with the attempt of the first two stanzas to express the origin of the self from chaos. From the perspective of the poem, the human is caught in the tension of no longer being able to call the highest thought God with a sense of ultimate certainty, but also of not falling into ultimate uncertainty, "since general-theoretical statements no longer work at this point and insight passes over into practice and knowledge into hope"73. In this same vein and as will be shown at the end of the poem, cognition turns into "care (Sorge)" (v. 105-108).

The talk of that joy which is almost too small (v. 10o) to still be able to grasp God is again to be considered as an act of reflection on poetry within the poem in that it turns back to the poem, which is, after all, characterized by a repeatedly appearing joyful mood. All this joy about the homeland and the community of loved ones, described and prepared by a slow approach, was ultimately unable to lead back to the invocation of the name of God. Language, which in the fifth stanza was able to rise again due to the friendly reception in the homeland, did not lead to prayer - as it did when it first appeared in the third stanza - but

73 K. Appel, Christianity and a New Humanism, C. Absolute Knowledge and the Body of God, 26. 
rather to the recognition of silence and the utterance of an absence: "Often we must be silent; holy names are lacking" (v. 101). Joy appears strangely ambivalent: Admittedly, it is the fundamental reason why the poem speaks and without which it would be unable to say anything, which already became clear in the first two verses based on the "cloud, / Composing poems full of joy (Wolke / Freudiges dichtend)" (v. 1 et seq.). The poem nevertheless leads to a point where it is no longer able to disclose language and risks covering up this rift or covering up silence itself. Hölderlin's poem oscillates between the linguistic opening brought about by joy and the concealment of the necessity of different means of access that the divine and the human demand. It is, however, decisive that this movement leads to silence but not to falling silent. It becomes the articulation of an absence.

While at the beginning of the third stanza prayer and poem had shown themselves to be indistinguishable, the poem now becomes the articulation of the rupture of this cohesion. Even though there is much talk of God in the last two stanzas, it conveys that it is no longer able to name him. This had already been indicated at the first mention of the silence of God (v. 86), where language had not passed over into an invocation of God, and it is now addressed directly in the middle section of the sixth stanza. The heart may still beat and long for the invocation of God, but language no longer seems able to measure up to this: "Hearts beat and yet talk holds back? (Herzen schlagen und doch bleibet die Rede zurük?)" (v. 102) This designates a rupture in language, which can no longer name God and man. While the first two stanzas had made it possible for man to speak, based on the gifts granted by God, it now becomes apparent that man is about to lose the ability to name God.

We must ask whether Hölderlin gives any indication as to how this tension that runs through man may be expressed, or whether the poem tends to assume that the (modern) self is no longer able to place itself in the fragile tradition that began with Enosh and which associated the name of God with a new name for man, i.e., a new form of humanity. Or, in other words: Does the poem still give an outlook on the aforementioned "almost" (v. 10o)? A final, epilogical section follows, which begins with "but":

Aber ein Saitenspiel leiht jeder Stunde die Töne,

Und erfreuet vielleicht Himmlische, welche sich nahn.

${ }^{105}$ Das bereitet und so ist auch beinahe die Sorge

Schon befriediget, die unter das Freudige kam.

Sorgen, wie diese, muß, gern oder nicht, in der Seele

Tragen ein Sänger und oft, aber die anderen nicht.

But string-music lends its tones to every hour, 
And perhaps brings joy to the heavenly who draw near.

${ }^{105}$ This makes ready, and care too will almost be

Appeased, which came into our joy.

Cares like these, whether he likes it or not, a singer

Must bear in his soul, and often, but the others not.

After the mention of the silence and the lagging behind of speech, the "but" (v. 103) leads to "string-music," which lends its tones to every hour (v. 103). The term hour, however, does not designate an abstract measure of time but the time in which the indisposability of language could become an invocation of the name of God ("And perhaps brings joy to the heavenly who draw near.", v. 104). Thus, we already encountered the hour without mediation in the poem Die Meinige ("Dear God! the hour was so beautiful / As the quiet voice called you Abba!" Die Meinige, v. 133); in Homecoming it had to develop: It appears for the first time in the first stanza in the context of the constitution of time, namely as that time which expresses the rise of the sacred ("and the holy / Hours", v. 9 et seq.). Later it appears as the time that may not remain "without the joyful ones (ohne die Frohen)" (v. 94) and refers to the sanctification of joy (v. 95 et seq.), namely in the constitution of community. Finally, as wordless song (Heidegger), it is saved by the string-music from becoming soundless and from falling back into a merely chronological order, which could be filled with arbitrary content. In this way it is to be kept open for the naming of the holy names.

Heidegger's interpretation of the passage also points in this direction:

To say who He himself is who dwells in the holy, and in saying this to let him appear as himself - for this the naming word is lacking. This is why poetic 'singing, because it lacks the genuine, naming word, still remains a song without words - 'lyre-music.'74

The wordless song does not become a substitute for the holy names but keeps the absence in language open against possible forms of substitution and keeps their memory alive:

Thus for the poet's care there is only one possibility: without fear of appearing godless, he must remain near to the god's absence, and wait long enough in this prepared nearness to the absence till out of the nearness to the absent god there is granted an originative word to name the high one. ${ }^{75}$

74 M. Heidegger, Elucidations of Hölderlin's Poetry, 45 et seq.

75 Ibid., 46 et seq. 
Heidegger does not speak of a renewed arrival or of a new immediacy of God, but rather of remaining close to his absence, which could grant the originative word that is able to call upon the high one again. The concern of poetic singing is for language, lest it be reduced to mere functionality when it lacks the name of God as the element of indisposability. For Heidegger, wordless song must turn into waiting and preparing and thus remain close to the absence of God. This means, first of all, acknowledging that poetry itself is not ultimate or absolute, nor can it adopt an absolute position; rather, it is a testimony to the indisposability of such a position. Indisposability must be made visible in the language of the poem. If merely asserted, it would remain in the realm of intentionality. In this way, poetry would have to remain open, so that in the interstices and transitions, in the steps of its development, in the slightest awareness of a vibrating openness that is no longer intentional, an originative word could appear. This would not simply be the name of God but the word that comes from silence, i.e., from an area of indisposability. And this word could become an opening of new horizons of language (an opening of much, v. 37) - and could "perhaps" (v. 104) also lead to the high one being called upon. But for this possibility, poetry cannot provide any ultimate certainty. The concern of poetry is to make that testimony of indisposability appear anew in language. Around that a form of kinship (which is no longer understood genealogically or ideologically) can be constituted.

In this last section we have reached the epilogue of the poem. While the poem has risen from a pre-reflexive sphere that did not yet know a speaking self, at the end it leads back into a sphere where reflection and intentional assertion break off. Speech, having already passed into silence, has no control over this sphere and can no longer moderate it. Delayed, speech remains behind ("yet talk holds back (doch bleibet die Rede zurük)", v. 102), i.e., a distance opens which the self can no longer close. Thus, an underivable shifting step [unableitbarer Versetzungsschritt] has taken place, by which the self must recognize that its language has always lived from the presupposition of an indisposability that has the characteristics of a gift and cannot be reached from any standpoint accessible to the self. This can be explained by a phrase from Hegel, taken up from the inaugural lecture, which can be expressed as the experience that "being-in-and-for-itself' is 'positedness"'76. Hölderlin hopes that (as was the case with the chaos and the pre-reflexive beginning rising out of it) this sphere will stand under the joyfully dense cloud (v. 1 et seq.) and that the postponement (the leaving behind of speech, v. 18) could show itself

76 K. Appel, Christianity and a new Humanism, A. The World as Mirror of the Self and its Shattering - Consciousness, Self-Consciousness, Reason and Spirit in Hegel's Phenomenology of Spirit, 18). In German: dass “das Anundfürsichsein Gesetztsein ist”. 
as a release of language into its indisposability. This postponement is about the underivable construction of a sound body from which language can once again become audible, or - expressed in Hölderlin's terms - about the return to that silence and that stillness from which the word of poetry first emerges.

With the passing of the name of God, poetry also passes: "Often we must be silent." (v. 101) The becoming and passing of poetry are expressed in the poem itself, indicating a radicalization of the self-reflexive dimension of Hölderlin's poetry, which had previously articulated the conditions of poetry's existence but now also addresses its ending. This marks a farewell to any attempt to linguistically cope with reality, where the notion of God could still function as the ultimate symbol used to bring the world under an abstract principle. And yet this passing must not be sealed by the silence of a nothingness that would pass definite judgment on contingent reality. The paradoxical task of poetry is now make its ending audible and thus to create an open sound body from which language and poetry can rise again. Perhaps, where linguistic control and noetic attempts at coping break down, a new perception of shifts, nuances and slight developments can lead to an uncontrollable abundance - and with this perception a new form of human tangibility. The poet's concern is to be faithful to the initial linguistic quality that made poetry possible in the first place, against the danger of its falling silent. It must rise anew, admittedly no longer smooth and perfect but with a fragility that can no longer be veiled, and always on the verge of failure. In his poetry Hölderlin has, as it were, outlined a path to the fragility of contemporary poetry.

In Homecoming, there is no immediate return to the name of God, since the motif of returning home in the poem itself proved to be deeply ambivalent and led precisely not to the name of God. Rather, HIS name can - perhaps - be found at the fractures, shifts and transitions, if these are not hidden, and can give expression to the threatened existence of man (the whole poem was not least concerned with the fragile constitution of man out of devouring chaos). The title of the poem would then acquire the new tone of a homecoming of the gods and of the God in song, which would be connected with a new language for the human. This new attention to language would be a prerequisite for any attempt at a coming humanism.

\section{Epilogue: From an Anachronistic Search for God (Musil) to Prayer (Rilke)}

During his student days and in the years that followed, all of Hölderlin's guiding ideas were shattered, and neither utopia, nor memory, nor the "now" of the present moment, nor timelessness held true as a place for the divine to reveal 
itself. It has become clear, however, that for Hölderlin this does not mean that the name of God simply disappears, but rather that it can find new ways of expression at the fractures, in the displacements and shifts, and that it must thus be linked to the opening of a new linguistic horizon. In this way, it is neither to be seen as utopian in the sense of being pending nor retrospective in the sense of a linguistic relic that needs to be revitalized, nor can it be fixed in contemporary images. Rather, to use a word from the inaugural lecture, it is anachronistic $^{77}$. This brings us, via Hölderlin, to the exact point where the epilogue of the inaugural lecture takes us into the anachronistic search for God in Musil's novel The Man without Qualities (Der Mann ohne Eigenschaften).

In contemporaneity with Musil, Rilke takes a similar track in his anachronistic search for God. Many of the motifs that I took up from the inaugural lecture and to which I would like to juxtapose similar motifs are bundled together in Rilke's poetry.

If, in the context of these reflections, Rilke's poetry finds its place in this epilogue, it is because it is poetry after Hölderlin: There the reflection on the loss of the name of God and thus of poetry revealed itself, and from this silence a new linguistic horizon emerged, one which was able to retrieve the name of God at the fractures of language. In my opinion, a possible approach to contemporary poetry could consist in understanding it as inhabiting precisely that space which Hölderlin reopened. This interpretation is supported by the fact that, since the beginning of the 2oth century, there are a large number of poems that address Friedrich Hölderlin - not least those that reflect on poetry itself. In the introduction to the anthology An Friedrich Hölderlin. Gedichte aus 180 Jahren deutsch- und fremdsprachiger Autoren, Dierk Rodewald says that the compilation of the poems "to and about Hölderlin" is guided by the assumption that

in the productive confrontation of the poets with the oeuvre of Friedrich Hölderlin, who is usually regarded as an exemplary figure of the poet, something like a lyrical reflection of the respective author on poetic speech as such can be detected ${ }^{78}$.

77 Cf. K. Appel, Christianity and a new Humanism, B. Moonbeams by Daylight, 32.

78 D. Rodewald, An Friedrich Hölderlin. Gedichte aus 180 Jahren deutsch- und fremdsprachiger Autoren, Frankfurt a. M. 1969, 7. An even more recent work, Scardanelli by Friederike Mayröcker (F. Mayröcker, Scardanelli, Frankfurt a. M. 20o9), should be added to the extensive collection. Scardanelli is the name that Hölderlin used to sign many of the poems that he wrote in his tower. 
He sees Rilke as the main impetus for this perception of Hölderlin, since Rilke had been intensively occupied with Hölderlin since 1911 and wrote the poem An Hölderlin in $1914^{79}$, which "set a point from which [...] it then became possible to productively take up Hölderlin's achievements concerning the lyrical poem"80.

In the following I would like to ask whether these considerations can reveal a perspective on Rilke's anachronistic search for God. ${ }^{81}$ I refer in particular to the first part of Rilke's Book of Hours, the Book of Monastic Life written in $1899 .{ }^{82}$ In the Christian tradition, a "book of hours" is the prayer book that contains the psalms in a certain order, so that they can be prayed at certain hours of the day - thus structuring it. Rilke's Book of Hours is a collection of poems in which God is addressed directly again and again, or else resonates unnamed as a dark keynote. As in Hölderlin, we again meet a poet in whom prayer and poem are indistinguishable, and the question about the name of God in all its fragility arises again: "You have this imperceptible way with you. / And those who would consecrate a blare of divine names / are already alienated from your environs. (Du hast so eine leise Art zu sein. / Und jene, die dir laute Namen weihn, / sind schon vergessen deiner Nachbarschaft.)" (50) In order to remain in the vicinity of this fragile context, let us first turn to Musil, who a few weeks after Rilke's death dedicated a commemorative speech to the poet in the Berlin Renaissance Theater, at the end of which he emphasized the anachronistic religious dimension in Rilke's work:

79 See R.M. Rilke, Die Gedichte, Frankfurt a. M./Leipzig 20o6, 626 et seq.; 854.

80 D. Rodewald, An Friedrich Hölderlin, 11.

81 There are numerous examples of how Hölderlin and Rilke are associated with each other, which I cannot go into here: Cf. R.M. Rilke/N. v. Hellingrath, Briefe und Dokumente, ed. by von K.E. Bohnenkamp (Castrum Peregrini, Neue Folge, Bd 1), Göttingen 2008; M. Heidegger, Wozu Dichter?, in: idem, Holzwege, Frankfurt a. M. 82003, 269-320; F. Heckerling, Rilke und das Christentum. Vom Erlebnis Spaniens zu den "Duineser Elegien", in: Wort und Wahrheit 12/1947 (2. Jg.), 755-759; R. Musil, Rainer Maria Rilke. Rede, gehalten am 16. Jänner 1927 im Renaissance-Theater Berlin, in: Robert Musil. Prosa und Stücke, Kleine Prosa, Aphorismen, Autobiographisches, Essays und Reden, Kritik, ed. by A. Frise, Reindek beim Hamburg 2000, 1229-1242; G. Agamben, Herrschaft und Herrlichkeit. Zur theologischen Genealogie von Ökonomie und Regierung (Homo Sacer II.2), Berlin 2010, 281-285; W. Binder, Hölderlin-Aufsätze, Frankfurt a. M. 1970, 397 et seq.

82 Cf. R.M. Rilke: The Book of Hours. A New Translation with Commentary. Translated by Susan Ranson. Edited with an Introduction and Notes by Ben Hutchinson. Columbia MD 2012. The numbers in brackets after the poems refer to the page numbers in the book, which always gives the German version first and then the English translation. Many of the reflections on Rilke's Book of Hours arose in joint reading with Simone Pesendorfer, whom I would like to thank warmly. 
When he says God, he means it, and when he speaks of a flamingo, he also means it; therefore, all things and events in his poems are related to each other and change places like the stars that move without being seen. He was in some sense the most religious poet since Novalis, but I'm not sure if he had a religion at all. He saw differently. In a new, inner way. ${ }^{83}$

Musil considers the religious dimension in Rilke's work less as religion appearing explicitly than as a form of a new, interior view, which approaches the "firebrand" of things ("Brand" der Dinge; 78 et seq.), or, to use Hegel's words, their negativity. This perception is opposed to a commanding grip upon or a mechanistic-positivist understanding of things, the world, man, God and language, and it requires an exercitium. The Book of Hours is the breviary that - when it is read (and prayed?) repeatedly - is intended to allow this perspective to be put into practice. Its first poem begins with the chime of the bell, which is an invitation to pray at a certain hour: "Bright with metallic strike, the hour / tilts, and touches me (Da neigt sich die Stunde und rührt mich an / mit klarem, metallenem Schlag)" (2 et seq.). And it ends with the dedication to those who learn to read the poet's (or the praying person's) images, so that their soul is released from fixed and frozen things and opens itself to a new perception: "Who is to say / in whom it will free the soul? ... (und ich weiß nicht wem / löst es die Seele los ...)" ( 2 et seq.). Later, a transformation of language into prayer takes place: "Ultimately, prayer is the only end (Es gibt im Grunde nur Gebete)" (5o et seq.).

After the first poem, which appears like an entrance gate to the Book of Hours, six poems follow, which, as it were, unfold a dialogue between God and the darkness and which attempt to lead to a heightened awareness which can only reveal itself in the dark. The second poem calls God the "aged tower (uralter Turm)" (2 et seq.), around which the poet has been circling for a long time, his own being remaining dark: Is the poet (the one praying) a falcon, a storm, or does he himself entirely become song? In contrast to the desire to capture God in a malleable image, the third poem then focuses on God's darkness: "my God is dark, roots of secret weave / in hundreds that I cannot hear, drinking. / Simply, his warmth grows me. / I divine no more (Mein Gott ist dunkel und wie ein Gewebe / von hundert Wurzeln, welche schweigsam trinken. / Nur, dass ich mich aus seiner Wärme hebe, / mehr weiß ich nicht)" (4 et seq.) If, on the other hand, one wished to see God (or man) in the light and sought to depict him, one would only arrive at a flat surface or a devastating, devouring sight that man is not able to bear. And so the next poem begins with the words: "So

83 R. Musil, Rainer Maria Rilke, 1240. 
arbitrarily we may not paint you, / you who are dawn, from whom the morning rose. (Wir dürfen dich nicht eigenmächtig malen, / du Dämmernde, aus der der Morgen stieg.)" (4 et seq.) This caution and increased attention, which can only be learned and maintained in darkness and twilight, also becomes discernible at the beginning of the next poem: "I cherish my mind's hours of the dark, / in which the extended senses sink and deepen (Ich liebe meines Wesens Dunkelstunden, / in welchen meine Sinne sich vertiefen)" (6 et seq.). In the dark hours of the night, a special closeness to God can present itself to the poet:

\begin{abstract}
Du, Nachbar Gott, wenn ich dich manchesmal in langer Nacht mit hartem Klopfen störe, so ists, weil ich dich selten atmen höre und weiß: Du bist allein im Saal. Und wenn du etwas brauchst, ist keiner da, um deinem Tasten einen Trank zu reichen: Ich horche immer. Gib ein kleines Zeichen. Ich bin ganz nah.
\end{abstract}

Nur eine schmale Wand ist zwischen uns, durch Zufall; denn es könnte sein: ein Rufen deines oder meines Munds und sie bricht ein ganz ohne Lärm und Laut. (6)

My neighbour God, do I disturb your peace by knocking for you in the night? If so, it's that I scarcely hear you breathe, and know you are alone in all that space.

If you should need our help, no one is there to offer water to your unseeing hand.

I still listen for you. Give me a sign.

For I am near.

Between us only an insubstantial wall chances - barely, I think - to stand; for perhaps from your lips or from mine one call could break it through without a sigh or a sound.

(7)

The knocking expresses concern for God. Does it arise from the ambivalence of wanting to speak of a God whose withdrawal alone can be named? Between God and men there is an "insubstantial wall (schmale Wand)" (6 et seq.), of which it is said: 
Aus deinen Bildern ist sie aufgebaut.

Und deine Bilder stehn vor dir wie Namen.

Und wenn einmal das Licht in mir entbrennt, mit welchem meine Tiefe dich erkennt, vergeudet sichs als Glanz auf ihren Rahmen.

(6)

Your own images have built it round you.

They stand in front of you, ranged like names, and if there flames up in me that flare igniting your recognition in my heart it spends itself, brilliant, on their frames.

(7)

The pictures we paint of God and the names by which we call him are the wall that separates man and God. Deeper realization ("your recognition in my heart"), when it erupts in the poet (in the praying person), does not lead to the collapse of this wall, nor the destruction of the images. Rather, the perspective is drawn away from the pictures to their frames. That the images are no longer directly in view is what allows them to survive. Is this the recognition that the immediacy of God would consume us? What does it mean that brilliance and limitation ("frames") coincide ("it spends itself, brilliant, on their frames")? The poem fails to answer this question, since it ends with the image of homelessness and separation from God: "So that unstrung my senses lose their rare / haven in you, and I am set apart. (Und meine Sinne, welche schnell erlahmen, / sind ohne Heimat und von dir getrennt.)" (6 et seq.) God's vicinity ("For I am near.") has turned into homelessness, which is determined precisely by separation and by the fact that no one is a neighbor ("My neighbour God") anymore.

After another poem expressing the desire for silence, the first section on the question of God in the Book of Hours comes to an end. A first sensitization of perception has taken place, but it has led to a separation from God. While God was initially mentioned almost as a matter of course, the first section leads to the difficulty of remaining in his vicinity.

As a transition to a second series of closely related poems, a reflection on the poet's point of view follows, placing him on the fragile site of the threshold of disintegrating time and an uncertain future:

Ich lebe grad, da das Jahrhundert geht.

Man fühlt den Wind von einem großen Blatt,

das Gott und du und ich beschrieben hat

und das sich hoch in fremden Händen dreht. 
Man fühlt den Glanz von einer neuen Seite, auf der noch Alles werden kann.

Die stillen Kräfte prüfen ihre Breite und sehn einander dunkel an.

(8)

I am here just as the century goes. I feel the wind start and lift as a great page fans, written by God and you and me and turned high above us, by an unknown hand.

We feel the new leaf as a sheen, on which all possibilities arise.

The quiet forces test its height and breadth, looking each other darkly in the eyes.

(9)

If the poet is able to express this transition without wistfully wanting to fix the old images or to paint new ones arbitrarily, perhaps an underivable openness can unfold: "We feel the new leaf as a sheen, on which / all possibilities arise." (8 et seq.) Poetry now requires a new approach, which can no longer be found arbitrarily. The poet thus becomes a reader ("I read it as it rises in your Word (Ich lese es heraus aus deinem Wort)", 10 et seq.), and a second section of seven poems begins, which unfolds like a re-figuration of images from biblical primeval history (Cain and Abel, the Ark, the Fall, the building of the Tower). This section begins with the story of Cain and Abel ("However, before death, murder came (Doch vor dem ersten Tode kam der Mord)", 10 et seq.) and immediately brings up the fragile tradition of naming the name of God which unfolds after Abel:

Da ging ein Riß durch deine reifen Kreise und ging ein Schrein und riß die Stimmen fort, die eben erst sich sammelten um dich zu sagen, um dich zu tragen alles Abgrunds Brücke -

Und was sie seither stammelten, sind Stücke deines alten Namens.

(10) 
rending the circles of your sureties.

There rose a crying

that tore aside the voices

about to chorus in a manner

that they could phrase you,

carry you,

bridge over our abysses -

And since that instant they have stammered

only pieces

of your old name.

(11)

According to Rilke, the fragmentary naming of the name of God, which is connected with the fragile line Abel/Seth/Enosh, does not emerge from the assemblage of voices that, united and risen to a high point (of metaphysics), lead to the notion of God. This fragmentary naming of God can also be considered an echo of Abel's cry. Like a note to the reader, before the next poem it reads: "The voice of the young Abel (Der blasse Abelknabe spricht)" (10 et seq.), whereupon the silenced Abel speaks. He sees that humanity stands in his tradition and is lost in the face of the wrathful judgment of the brother: "Should others tread my path, not one / can hope to escape his anger; / to him, simply, they are no longer. (Es gingen alle meine Bahn, / kommen alle vor seinen Zorn, / gehen alle an ihm verloren.)" (10 et seq.) The text ends with an apocalyptic separation:

Ich glaube, mein großer Bruder wacht wie ein Gericht.

An mich hat die Nacht gedacht; an ihn nicht.

And my elder brother watches as if he sits there in judgement.

But night has remembered not him: me.

(11)

Two lines separate at this point: One is the view that considers the world to be faced with doom and thus guilty and lost. This perspective erupts again at various points in the Book of Hours, such as: "What is Rome? / All but scattered. / What is the world? / It will be shattered (Was ist Rom? / Es zerfällt. / Was ist die Welt? / Sie wird zerschlagen)" (18 et seq.). Rilke contrasts this with the darkness of night, which presents itself as a protection against the all-identifying, 
all-naming, all-illuminating and all-limiting light of judgment and condemnation: "But night has remembered /[...] me (An mich hat die Nacht gedacht)" (10 et seq.). This word is taken up again in the following poem, which starts with: "Darkness of night, out of which I came, / I love you more than the flame / that circumscribes the world (Du Dunkelheit, aus der ich stamme, / ich liebe dich mehr als die Flamme, / welche die Welt begrenzt)" (12 et seq.), and ends with the confession: "I believe in the night. (Ich glaube an Nächte.)" (12 et seq.). A new place has opened up for poets and those who pray, a place that can no longer be occupied high-handedly but lives by adherence to the tradition of Abel. Twice more a poem will address itself "To the same young monk (An den jungen Bruder)", which probably not least means Abel. From now on, the voice of the pale boy Abel continues to speak in poetry, which has now found a new ground where new language spaces can unfold, as the next poem - a continuation of "I believe in the night. (Ich glaube an Nächte.)" (12 et seq.) - expresses: "I believe in all that is not yet said (Ich glaube an Alles noch nie Gesagte)" (12 et seq.)

After the seven poems which re-figure motifs from biblical primeval history, a remark follows - again as a threshold to a new, large series of poems that probably refers to Christ and his relationship to God: "Because, once, He desired you, we too / know we are granted the right to seek you. (Daraus, dass Einer dich einmal gewollt hat, / weiß ich, dass wir dich wollen dürfen.)" (18 et seq.) In contrast to the first series, which ended with the separation from God and the request for silence, this poem, and thus the second course of reflection, leads to the words: "Desire him or not, God forgathers. (Auch wenn wir nicht wollen: / Gott reift.)" (18 et seq.)

The third series of poems that now follows and which constitutes the main part of the Book of Hours, seems to be devoted to the effort to protect that which is not said ("all that is not yet said", 12 et seq.). This concern finds expression in the phrase: "Some hymns I have that are my silence. (Ich habe Hymnen, die ich schweige.)" (48 et seq.). I would like to refer to a poem from this section, which summarizes the apocalyptic drama already mentioned in connection with Abel, and quote it in its entirety:

Dein allererstes Wort war: Licht:

da ward die Zeit. Dann schwiegst du lange.

Dein zweites Wort ward Mensch und bange

(wir dunkeln noch in seinem Klange)

und wieder sinnt dein Angesicht.

Ich aber will dein drittes nicht. 
Ich bete nachts oft: Sei der Stumme, der wachsend in Gebärden bleibt und den der Geist im Traume treibt, daß er des Schweigens schwere Summe in Stirnen und Gebirge schreibt.

Sei du die Zuflucht vor dem Zorne, der das Unsagbare verstieß.

Es wurde Nacht im Paradies: sei du der Hüter mit dem Horne, und man erzählt nur, daß er blies.

Your first word: Light - and time became.

Then you were silent. And from your second (we still darken at its ring) the human race took form - feared and now your face broods again.

However, I would not hear your third.

By night I plead into your ear: be just the mute, grounded here, growing in gestures, driven in dreams to write the heavy sum of silence on mountain face and countenance.

Be for us refuge from the wrath that cast out what shall not be borne. Night descended in Paradise.

Be you the guard, of whom one says just that he blew the horn.

Poem and prayer have once again become indistinguishable, and yet it seems that the weak tradition of the naming of the name of God has reached its outermost point of negation: It began with Enosh and led to the realization of the absence of the holy names with Hölderlin but had not fallen into silence. Here it leads to the plea that God may no longer speak and thus himself close the space that Hölderlin had once again tried to tear open. Let us now take a closer look at the four stanzas of the poem, three of which have the same number of verses, whereas the second consists of only one verse:

1) Summarized in two words ("Your first word", "your second", 35) the biblical story of creation appears at the beginning of the poem: The first word of God brought about light and led into a silence that implies the idea of resting 
in God. With the second word man appears; the poem however ingeniously leaves open whether it is the man of the sixth day of creation or the incarnate Word of the prologue of John's Gospel. Our life, which in the fourth verse appears only quietly in brackets, lives off the sound of the second word, even though Rilke here uses the word "dunkeln (darken)" for "leben (live)", as darkness dynamically turned into a verb, from which the boy Abel and the poet originate: "Darkness of night, out of which I came (Du Dunkelheit, aus der ich stamme), 12 et seq.)". In the word "bange (feared)" - which rhymes with the word used to describe God's silence ("lange (long)") and, through the minimal shift of only one letter, expresses the opposite of the silence that had previously occurred - the danger in which humanity is caught is revealed. Once again what becomes apparent is an apocalyptic alternative. The word "bange (feared)" refers to doom through judgment, ${ }^{84}$ whereas the alternative is a poetry that comes out of the night and is able to preserve the inexpressible: "Be for us refuge from the wrath / that cast out what shall not be borne. (Sei du die Zuflucht vor dem Zorne, / der das Unsagbare verstieß.)" (52 et seq.) In the English translation, the "inexpressible" has been lost. It should read: "that casts out the inexpressible". This apocalyptic alternative is introduced through the depiction of God's pondering face, behind which the poet suspects a third word: "However, I would not hear your third. (Ich aber will dein drittes nicht.)" ( 52 et seq.)

2) A Marian poem and an anti-Marian poem from the Book of Hours can help us understand this third word. In a poem starting with "In those days (Da ward auch die zur Frucht erweckte)" (36 et seq.), we read that Mary was "filled by the imparted, / sufficing for a thousand souls, / by all the world illuminated, / our vineyard for the Vine (so erfüllt von jenem Einen / und so für Tausende genug, / daß alles schien, sie zu bescheinen, / die wie ein Weinberg war und trug)" (36 et seq.). In apocalyptic descriptions of the decay of the buildings and the "song chanted for centuries long (Abgesang der Gesänge)" (36 et seq.), the following poem develops this image further to a counter-image of Mary, an anti-Mary, so to speak. If Mary stands for the birth of the Redeemer, then the anti-Mary stands for a scenario of disaster. She has turned, "undelivered of a burden more solemn, / turns to the pains to come (wie von Größerem noch unentbunden, / kommenden Wunden / zugekehrt)" (36 et seq.). But the poem is

84 Cf. "Today perforce / a history of the world is pressed / down on that brow before a severe court, / weighing it down under the sentence passed. (heut drängt / auf ihr sich eine Weltgeschichte / vor einem unerbittlichen Gerichte, / und sie versinkt in seinem Urteilsspruch.)" (28 et seq.). 
unable to imagine what it is that is coming, that is greater - it warns of it with a cry of woe: "Woe - the greatest is not yet born of her. (Wehe, sie gebar noch nicht den Größten.)" (36 et seq.) It addresses the arbitrary turning (anti-Maria has turned herself ...) towards that which is greater than the Incarnate Word, greater than the One who preserves in himself fullness for thousands and thus an unlimitable openness. To seek what is greater than the One must thus, through the denial of this openness, mean pronouncing a final judgement on the world. It would represent the striving of man, who is the second word, for a total view, which would constitute the third word and bring about "Night descended in Paradise (Nacht im Paradies)" (52 et seq.). It would be the third word, which would be spoken arbitrarily beyond the incarnation of the Word, in whose sound we darken. The poet asks God himself not to pronounce this third word, thereby expressing that the threat that accompanies it exceeds everything humanly imaginable. This request can no longer be addressed to humans, because human space has already been abandoned.

3) This request is then carried out in the last two stanzas and is designated as prayer: "By night I plead (Ich bete nachts oft)" (52 et seq.). In this poem, which is also a prayer, a reflection on prayer itself is thus once again evident, as was the case with Hölderlin. The poem asks God to be mute, because beyond his incarnate Word there is no conceivable greater word. But may this muteness remain, lest God cease to conceal himself from us. May God's faithfulness grow in gestures, i.e., in contingent gestures of humanity, which are preserved from the madness and excess of the third word.

4) And finally, may the mute God be the "refuge from the wrath / that cast out what shall not be borne (Zuflucht vor dem Zorne, / der das Unsagbare verstieß)" (52 et seq.). If the inexpressible were destroyed, e.g., by complete control of language (this would be the third word), there would no longer be any space from which new horizons of human language could arise. May God himself be the guardian of the inexpressible and not let the poet fail in his task of protecting the garden/text/language/name: "Cares like these, whether he likes it or not, a singer / Must bear in his soul" (Homecoming, v. 107 et seq.).

It is said that God, the guardian, has sounded his horn - is this an expression of the seriousness of the threat, or is it the sign of the night watchman who calls the hours and thus guides us through the night, in which everything would otherwise sink into disorientation?

With this poem, we have returned to where the inaugural lecture started, to day one of the First Creation Story (Priestly source), where it says, "And God called the light Day" (Gen 1:5). Rilke paraphrases this with the words: "Your first word: Light - and time became." Parallel to the line that went from the creation 
narrative, passing through Hegel's Phenomenology of Spirit, on to Musil's Man without Qualities, I wanted to follow a path from the story of Cain and Abel, passing through Hölderlin's poem Homecoming, to Rilke's Book of Hours, a path which addresses the question of the name of God, which is closely related to the gift of mortality. The Christian narrative or the narrative of Christianity in all its dimensions - from biblical revelation to its extrapolations and respective renditions - cannot be separated from the history of the name of God. Thus, in the present reflections the question has arisen repeatedly as to what forces are connected with its naming and falling silent. Theoretical answers, however, do not go far enough at this point; the die is cast on the question of whether the name of God is associated with the opening of new language horizons or not. If it is the task of Christianity to save the name of God, to which Jesus referred through his person and history, from falling silent, then part of this task is asking where Christianity itself can become a new opening of language horizons in the face of the all-threatening danger of the name's falling silent ${ }^{85}$. Christianity's contribution to a New Humanism would be to become a network of places where people can speak and begin to tell their individual stories. Moreover, it would have to open spaces and open doors to promote the becoming of poetry. Today, the Church is perhaps only conceivable as universal if it becomes a sound body that makes the silence of a whole generation - I mean young people - audible. ${ }^{86}$

When I think of the closing words of your inaugural lecture, which - quoting Musil - speak of the fact that the character of human activities should be measured by the number of words they require ${ }^{87}$, my text is worse off than your lecture. I conclude my long letter with a poem by Rilke, which can also be read as a prayer. As hardly any other text, it poetizes the transitory aspect of the times by lifting the threshold between summer and its epilogue, autumn, into the word:

85 Cf. K. Heinrich, Versuch über die Schwierigkeit nein zu sagen, Frankfurt a. M./Basel ${ }^{2} 1982$, 97-119.

86 Cf.J. Deibl, Hölderlin, Heidegger e il grido non udito della gioventù, in: Ma di' soltanto una parola ... economia, ecologia, speranza per i nostri giorni, Milano 2013, 359-371.

87 The concluding paragraph of K. Appel's inaugural lecture reads: "I will close with a quote from Musil, 'human activities might be graded by the quantity of words required: the more words, the worse their character." (K. Appel, Christianity andf a new Humanism, B. Moonbeams by Daylight 33; R. Musil, The Man Without Qualities, 264). 


\section{Herbsttag}

Herr, es ist Zeit. Der Sommer war sehr groß. Leg deinen Schatten auf die Sonnenuhren, und auf den Fluren lass die Winde los.

Befiehl den letzten Früchten, voll zu sein; gib ihnen noch zwei südlichere Tage, dränge sie zur Vollendung hin, und jage die letzte Süße in den schweren Wein.

Wer jetzt kein Haus hat, baut sich keines mehr. Wer jetzt allein ist, wird es lange bleiben, wird wachen, lesen, lange Briefe schreiben und wird in den Alleen hin und her unruhig wandern, wenn die Blätter treiben.

\section{Day in Autumn 88}

After the summer's yield, Lord, it is time to let your shadow lengthen on the sundials and in the pastures let the rough winds fly.

As for the final fruits, coax them to roundness. Direct on them two days of warmer light to hale them golden toward their term, and harry the last few drops of sweetness through the wine.

Whoever's homeless now, will build no shelter; who lives alone will live indefinitely so, waking up to read a little, draft long letters, and, along the city's avenues, fitfully wander, when the wild leaves loosen.

88 Translation by Mary Kinzie, cf. https://www.poetryfoundation.org/poetrymagazine/ poems/50937/day-in-autumn (last access: 7 December, 2020). 